\title{
Control of $\mathrm{NO}_{3}{ }^{-}$and $\mathrm{N}_{2} \mathrm{O}$ emissions in agroecosystems: A review
}

\author{
Gero Benckiser • Tanja Schartel • Achim Weiske
}

Accepted: 26 February 2015 / Published online: 23 April 2015

(C) INRA and Springer-Verlag France 2015

\begin{abstract}
Energized electron flows through biological systems sustain nature's complexity. They drive bacterial, archaeal, and fungal oxidation-reduction processes and enable to introduce $\mathrm{CO}_{2}$ and $\mathrm{N}_{2}$ from the atmospheric pool. Electron flux-based food webs convert soil organic matter (SOM) in virgin forest and permafrost soils, over-fertilized agricultural land, grassland systems, compost/wastewater treatment plants, oceans, rain forests, savannahs, and forests of the temperate climate zones, and have their strategy adapted on the system in which they are active. Thus, the electron driving power is responsible in our industrializing world that carbon and nitrogen returns to the atmosphere presently with an annual $\mathrm{N}_{2} \mathrm{O}-\mathrm{N}$ proportion of 0.5 to 4.2 terragrams $(\mathrm{Tg})$ or an annual atmospheric $\mathrm{N}_{2} \mathrm{O}-\mathrm{N}$ increase of $0.25 \% . \mathrm{N}_{2} \mathrm{O}$ is a 300-times more potent greenhouse gas than $\mathrm{CO}_{2}$. Nature's water-soluble soil carbon $\left(\mathrm{C}_{\mathrm{H} 2 \mathrm{O}}\right) / \mathrm{NO}_{3}{ }^{-}$ratio balancing is seen as a model of how $\mathrm{N}_{2} \mathrm{O}$ emissions could be kept in a tolerable range. Sub strategies beyond are (a) an annual 400 800 terragrams ( $\mathrm{Tg})$ photosynthate-C (90-95\% sugars) release into plant rhizospheres, (b) spot-wise $\mathrm{N}$ enriching animal excrement and wide $\mathrm{C} / \mathrm{N}$ ratio litter fall distributions, (c) viral shunts or life shortcuts to supporting $\mathrm{O}_{2}$ consuming, $\mathrm{N}$ supplying, and denitrifying recycler communities, (d) subterranean organic-inorganic soil components mixing and $\mathrm{O}_{2}$ diffusion promoting $\mathrm{NO}_{3}{ }^{-}$formation, and (e) the release of nitrification inhibiting compounds as neem, karanjin, or specific
\end{abstract}

G. Benckiser $(\square)$

Institute for Applied and Soil Microbiology, Justus Liebig University, 35392 Giessen, Germany

e-mail: Gero.Benckiser@umwelt.uni-giessen.de

T. Schartel

Chemisches und mikrobiologisches Institut, $U E G \mathrm{GmbH}$,

D-35578 Wetzlar, Germany

e-mail: t.schartel@ueg-gmbh.de

A. Weiske

ÖkoP Zertifizierungs GmbH, Schlesische Straße 17d,

94315 Straubing, Germany

e-mail: achimweiske@oekop.de humic acids which help in controlling nitrate formation and denitrification. Soil microbial transport vehicles are fungal hyphae, plant roots, and subterranean animals. Through their activities, aerobic-anaerobic gradients in the soil crumb mosaics emerge. Plant root intertissue spaces, animal guts, and co-transported soil crumbs where under carbon-dominated $\mathrm{C}_{\mathrm{H} 2 \mathrm{O}} / \mathrm{NO}_{3}{ }^{-}$ratios preferred microbes reside are mobile locations in well-aerated soils. In such reduction-equivalent surplus environments, denitrifying communities are forced to use during anaerobic respiration available nitrate-, nitrite ions, $\mathrm{NO}$, and $\mathrm{N}_{2} \mathrm{O}$ economically. Though at carbon-dominated $\mathrm{C}_{\mathrm{H} 2 \mathrm{O}} / \mathrm{NO}_{3}{ }^{-}$ratios more $\mathrm{N}_{2} \mathrm{O}$ is reduced to $\mathrm{N}_{2}$ than in nitrate surplus environments, a complete prevention of $\mathrm{N}_{2} \mathrm{O}$ emissions is not a reality and even not desirable from the climate point of view. After describing $\mathrm{N}_{2} \mathrm{O}$ formation and emissions from a compost pile, a municipal wastewater treatment plant, a constructed wetland, and mineral $\mathrm{N}$-fertilizer, sewage sludge or nitrification inhibitor-stabilized $\mathrm{N}$-fertilizer amended soils with their aerobic-anaerobic mosaics, this review tries to deduce exercisable $\mathrm{CN}\left(\mathrm{C}_{\mathrm{H} 2 \mathrm{O}} / \mathrm{NO}_{3}\right)$ ratio shaping and $\mathrm{N}_{2} \mathrm{O}$ emission lowering strategies for ecologists, agriculturists, and waste managers in our industrializing world.

Keywords Ecosystems $\cdot \mathrm{C}_{\mathrm{H} 2 \mathrm{O}} / \mathrm{NO}_{3}{ }^{-}$ratio management . Nitrification · Denitrification $\cdot \mathrm{N}_{2} \mathrm{O} \cdot \mathrm{CO}_{2} \cdot \mathrm{CH}_{4}$ emissions . Compost $\cdot$ Sewage sludge $\cdot$ Constructed wetlands $\cdot$ Fertilized fields · Organic amendments $\cdot$ Nitrification inhibitors

Contents

1 Introduction

$2 \mathrm{~N}_{2} \mathrm{O}$-formation in composting biowaste

$3 \mathrm{~N}_{2} \mathrm{O}$-formation and emission in and from wastewater

$4 \mathrm{~N}_{2} \mathrm{O}$ formation and emission from a constructed wetland

5 Actual and potential denitrification in sewage sludge and/or mineral fertilized Parabrown earth field plots

6 Nitrification inhibitor effects on $\mathrm{N}_{2} \mathrm{O}$ emissions from wastewater and soil

$7 \mathrm{CN}$ ratio dependent $\mathrm{N}_{2} \mathrm{O}$ emissions 
8 Denitrification strategies

$9 \mathrm{C}_{\mathrm{H} 2 \mathrm{O}} / \mathrm{NO}_{3}{ }^{-}$ratio managing possibilities

10 Conclusions

\section{Introduction}

In many developing countries, there is not only a continuing unscientific usage of chemical fertilizers, pesticides, and urban refuse material with adverse consequences on bradyrhizobial populations, VA mycorrhiza, nematodes, earthworms, and growing, aphid-punctured plants (Fig. 1) but also on soil biological quality and agricultural sustainability. From organic farm soils receiving plant uptake adapted organic amendments, it is known that more copiotrophs (+52-119\%), oligotrophs ( $+25-79 \%$ ), actinomycetes (92 to $100 \%$ ), more of the arbuscular mycorrhizal protein, glomalin, are present than in conventionally treated fields (Chander and Brookes 1991; Lambers and Weidensaul 1991; Weiss and Larink 1991; Madariaga and Angle 1992; Morgan and Morgan 1992; Vega et al. 1992; Christie and Kilpatrick 1992; Roldan and Alexander 1993; Malhotra et al. 2015). Quantifications of $16 \mathrm{~S}$ rDNA qPCR abundances showing a 1.8-fold increase in both organic cropping and organic orchard soils and a 22-fold ammoniumoxidase $\mathrm{A}$ gene decrease in organic cropping and orchards allow to conclude that organic amendments improve the biological quality and may thus be appropriately included in the group of Ecosystem Engineers that selectively modify the environment and make soil ecosystems more sustainable (Aparna et al. 2014).

The Earth's atmosphere contains around $20 \% \mathrm{O}_{2}$ and, consequently, in converting virgin forest and permafrost soils, $\mathrm{N}$ over-fertilized monocultures, $\mathrm{CN}$ highly enriched compost/ wastewater treatment plants or sewage up taking river networks, to mention some productive environments, energy

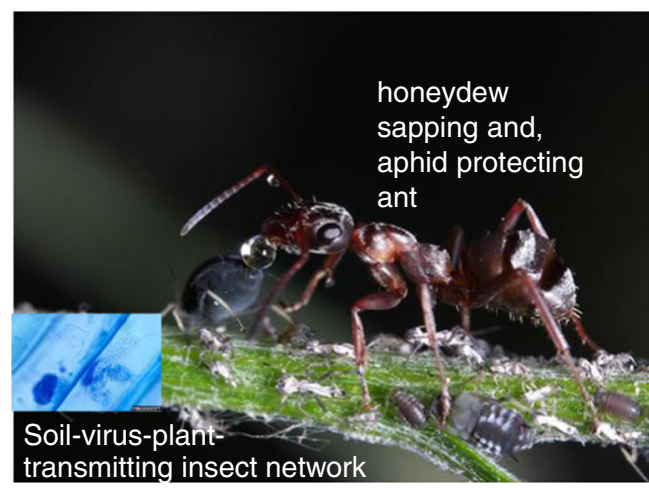

Fig. 1 Soil borne wheat mosaic virus (Furovirus SBWMV (Florida Division of Plant Industry Archive, Florida Department of Agriculture and Consumer Service; http://www.forestryimages.org/browse/detail. cfmimgnum $=5266027$ \#sthash.pSQu8HbE.dpuf and a phloem-sucking, honeydew-excreting aphid, protected by honeydew-imbibing ant (photo publication authorized by Thomas Griessler breschniak@gmx.net) conservation is hierarchically organized (Klüber and Conrad 1998). After $\mathrm{O}_{2}$-consuming aerobic respiration and nitrification-denitrification set in at first among the anaerobic processes whereby annually $\mathrm{N}_{2} \mathrm{O}$ in amounts of $0.5-4.2 \mathrm{Tg} \mathrm{N}_{\text {year }}{ }^{-1}$ at annual increase of $0.25 \%$ are released into the atmosphere (Fig. 2; Michel and Wozniak 1998; Steffen et al. 2011; Crutzen et al. 2008; Ravishankara et al. 2009; Rockström et al. 2009; Akiyama et al. 2010; Steffen et al. 2011; Gross 2012; Decock and Six 2013; Yu et al. 2013; Benckiser et al. 2015). The emission of $\mathrm{N}_{2} \mathrm{O}$ depends in their magnitude on $\mathrm{N}_{2}$-fixation, a process which is closely conjoined with photosynthesis (Fig. 2). Ammonium, the result of $\mathrm{N}_{2}$-fixation is oxidized to $\mathrm{NO}_{3}{ }^{-}$and this $\mathrm{NH}_{4}{ }^{+}$formation and oxidation to nitrate depends on altitudinal-latitudinal allocation gradients of leaf and root litter, fertilizer-excrement distributions, seasonality, length of dormant periods, microclimate (freeze-thaw cycles, precipitation, solar radiation), $\mathrm{O}_{2}$ availability, microbial conversion activities, $\mathrm{NH}_{4}{ }^{+}$-release, $\mathrm{NH}_{4}{ }^{+}$biomass-humus-clay binding, spatially-temporally occurring vegetation-food web interactions, viral shunts, biomass burning and industry contributions, and denitrifier/nitrate ammonifier community activities returning the $\mathrm{NH}_{4}{ }^{+}$introduced by $\mathrm{N}_{2}$-fixation as $\mathrm{NO}$, $\mathrm{N}_{2} \mathrm{O}, \mathrm{N}_{2}$, or $\mathrm{NH}_{3}$ back to the atmosphere from where it came (Figs. 2, 3, and 4; Scherer 1993; Benckiser 1997; Filip et al. 2000; Benckiser and Bamforth 2011; Nacry et al. 2013). A prerequisite for $\mathrm{NO}_{3}{ }^{-}$formation is a good $\mathrm{O}_{2}$ availability, while the $\mathrm{NO}_{3}{ }^{-}$returning denitrification process as the

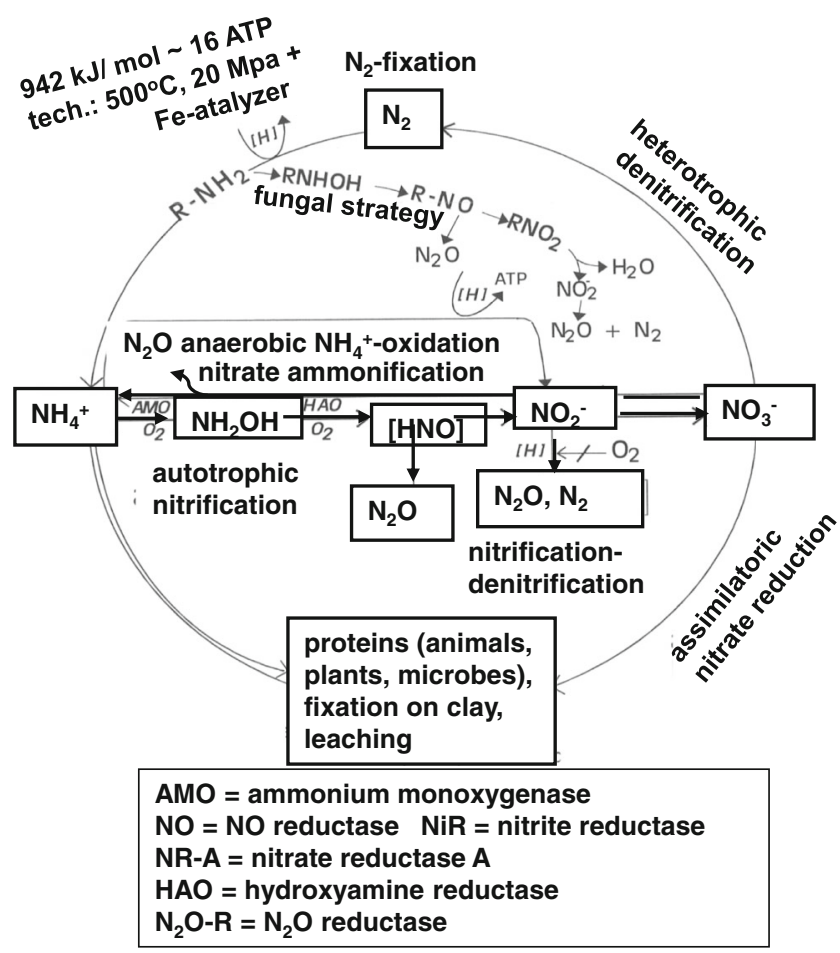

Fig. 2 Nitrogen cycle in terrestrial and aquatic ecosystems (Arcand et al. 2013; Flasconaro et al. 2013; Benckiser et al. 2015) 


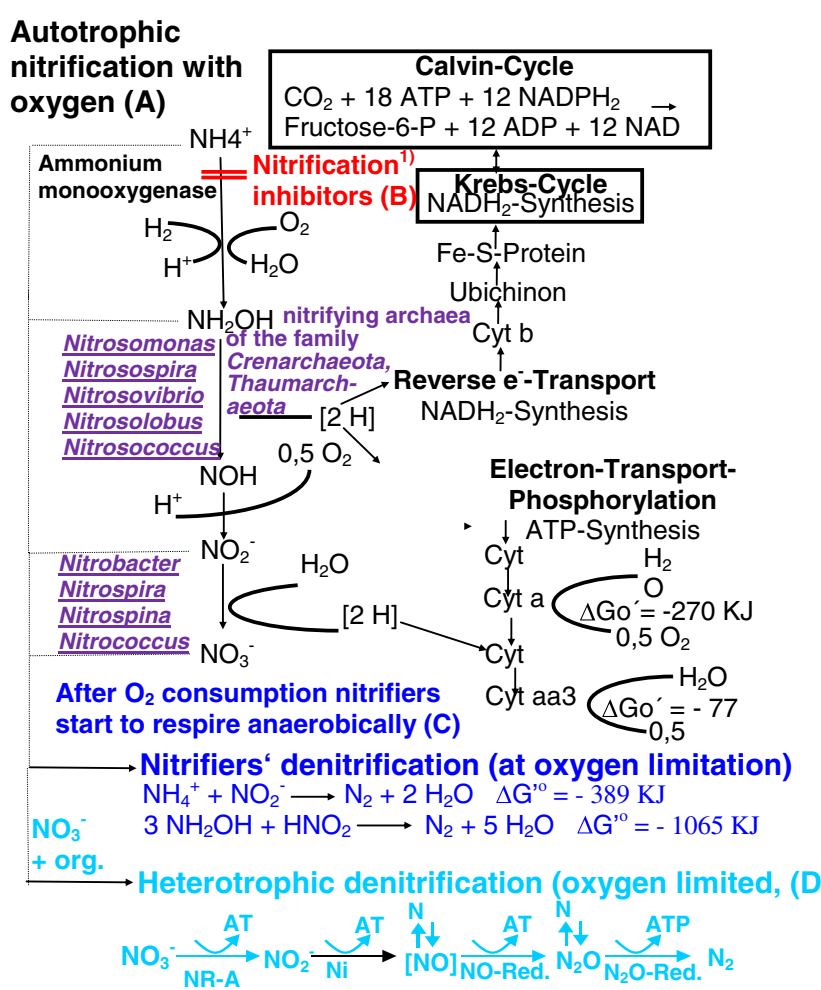

Fig. 3 Nitrite, nitrate, biomass formation, and energy gains during autotrophic nitrification (the nitrification process needs oxygen for conserving ATP and can be inhibited with compounds like $\mathrm{N}$-allylthiourea, dimethylether, acetylene $\left(\mathrm{C}_{2} \mathrm{H}_{2}\right)$ nitrapyrin (2-chloro-6trichloromethyl-pyridine), 3,4 dimethyl pyrazolephosphate (DMPP) or dicyandiamide $(D C D)$. After $\mathrm{O}_{2}$ consumption, nitrifiers can gain energy by respiring anaerobically the aerobically formed nitrate with $\mathrm{NH}_{4}{ }^{+}$ derived electron and protons. This additional energy conserving possibility differs from heterotrophic denitrification where reduction equivalent are of organic origin) in comparison with anaerobic nitrate respiration by nitrifiers' denitrification and heterotrophic denitrification and the control possibility by nitrification inhibitors $(N I)$.

succeeding anaerobic respirations and fermentations are blocked in presence of $\mathrm{O}_{2}$. In soil crumbs with their aerobicanaerobic gradients, all oxidizing and reducing activities occur simultaneously and thus the resulting gaseous emissions collected in soil covers are mean values of all aerobic and anaerobic soil processes (Benckiser et al. 1984; Klüber and Conrad 1998; Trost et al. 2013).

Until the end of the nineteenth century, $\mathrm{N}_{2}$ fixing, nitrifying, and denitrifying bacteria and archaea shaped the world's $\mathrm{N}$ demand (Figs. 2 and 3) and $\mathrm{N}$ shortage was the norm. The worldwide adapting plant communities counteracted to overcome N-related growth limitations by transporting annually 400-800 Tg photosynthate-C (90-95\% sugars) into their rhizospheres for attracting free-living and symbiotic $\mathrm{N}_{2}$ fixing bacteria. Besides, the height of $\mathrm{N}_{2} \mathrm{O}-\mathrm{N}$ emissions was controlled by using $\mathrm{N}_{2} \mathrm{O}$ as electron acceptor economically. In addition to nitrification and $\mathrm{N}_{2} \mathrm{O}+\mathrm{N}_{2}$ loss controllers as $\mathrm{N}_{2}-$ fixing microbial activities, a distribution of wide $\mathrm{C} / \mathrm{N}$ ratio litter fall, soil clay-humus complex and biomass $\mathrm{NH}_{4}{ }^{+}$binding, and release of nitrification-inhibiting compounds such as neem, karanjin, or certain humic acids were and are still employed for $\mathrm{C}_{\mathrm{H} 2 \mathrm{O}} / \mathrm{NO}_{3}{ }^{-}$ratio balancing (Hassett et al. 1987; Scherer 1993; Majumder et al. 2001 and 2004; Kehr 2006; Tadeno and Takeda 2010; Abasi et al. 2011; Carvalhais et al. 2011). Nitrifying bacteria and archaea and the denitrifying communities among the $10^{30}$ annually newly produced in biofilms around rhizospheres and soil particles consume oxygen and absorb soil nutrients. Bacteria, archaea, fungi, and protists switch after oxygen consumption by using alternatively $\mathrm{NO}_{3}{ }^{-}, \mathrm{NO}_{2}{ }^{-}, \mathrm{NO}$, and $\mathrm{N}_{2} \mathrm{O}$ as electron acceptors (Figs. 2 and 3). If the availability of $\mathrm{NO}_{3}^{-}, \mathrm{NO}_{2}{ }^{-}, \mathrm{NO}$, and $\mathrm{N}_{2} \mathrm{O}$ is low but the availability of electron donors high, then an economic thinking sets in and $\mathrm{N}_{2} \mathrm{O}$ is preferred reduced to $\mathrm{N}_{2}$ or even to $\mathrm{NH}_{3}$ before it can escape from the cell membrane into the surrounding cell atmosphere (Tiedje 1988; Simarmata et al. 1993; Benckiser 1997, 2007a, b, 2010; Ottow 2011; Decock and Six 2013; Cabello et al. 2004; Bardgett and Wardle 2010; Flemming and Wingender 2010; De Long 2012). If $\mathrm{N}_{2} \mathrm{O}$ reached the atmosphere, recapturing is limited (Vieten et al. 2008).

Subterranean digging animals like earthworms ingest and digest inorganic, organic components, and microbes, deposit their excrements in ducts, and promote oxygen diffusion into soils similarly as aerenchyma tissues (Benckiser et al. 1984; Horn et al. 2006). In rhizospheres diffusing oxygen finds an electron surplus condition and are comparable to soil crumb environment where virus genomes integrating microbes are active in water-filled pores, which are closely neighbored by air-filled pores (Benckiser 1997; Benckiser and Bamforth 2011). ATP-conserving microbes in soil crumbs respire with $\mathrm{O}_{2}$, alternatively with electron acceptors as $\mathrm{NO}_{3}{ }^{-}, \mathrm{NO}_{2}{ }^{-}, \mathrm{NO}$, $\mathrm{N}_{2} \mathrm{O}, \mathrm{Fe}(\mathrm{III}), \mathrm{Mn}(\mathrm{IV}), \mathrm{SO}_{4}{ }^{2-}, \mathrm{CO}_{2}$ or ferment by using internal organic electron acceptors. Fast multiplying microbes at good growth conditions are subjected to virus-mediated life short cuts (viral shunts; Engelhardt et al. 2013). Occurring cell bursts provide the surviving microbial community with additional nutrients, which improve the growth of the survivors (Fig. 4). From oligotrophic lakes and oceans, it is known that virus-mediated cell lysis is a major $\mathrm{C}, \mathrm{N}$, and trace element contributor (viral and cell DNA/RNA CN ratio $=2$; bacterial $\mathrm{CN}$ in the exponential growth phase around 3-4; Säwström et al. 2007). The role of viral shunts in soil ecosystems is still a black box (Sime-Ngando 2014). Animals and root-fungal hyphae systems are locations and transport vehicles for viral genomes carrying microbes in well and less well-aerated soils. If reduction equivalent luxuriously available and the electron acceptors nitrate, nitrite $\mathrm{NO}$, and $\mathrm{N}_{2} \mathrm{O}$ low concentrated as in rhizospheres or animal guts then the denitrifying communities are forced to think economically and less $\mathrm{N}_{2} \mathrm{O}$ will be emitted (Figs. 2 and 3; Benckiser et al. 1984; Tiedje 1988; Benckiser 1997; Klüber and Conrad 1998; Chapman et al. 2006; 
Fig. $4 \mathrm{~N}$ and virus cycling through terrestrial ecosystems whereby virus mediated cell burstings, viral life shortcuts, viral shunts contribute to the nutrient supply (adapted from Benckiser 2007b and 2010; Babikova et al. 2013; Engelhardt et al. 2013; Sime-Ngando 2014)

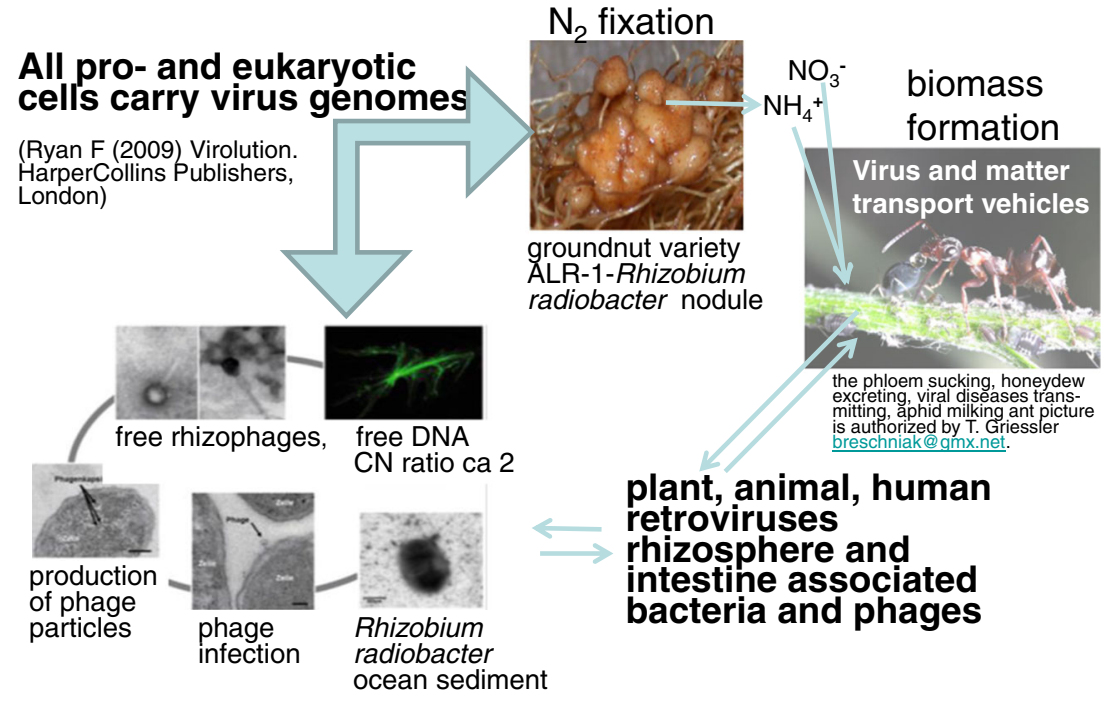

Benckiser 2010; Depkat-Jakob et al. 2010). Plants growing in submerged soils as reed or rice try to keep root respiration going by transporting oxygen in aerenchyma tissue from leaves down to the roots. Thereby, the magnitude of anaerobic energy conservation is concomitantly controlled (Benckiser et al. 1984). Plants also try to avoid too high oxygen consumption by swaying nitrification-inhibiting compounds (Hassett et al. 1987; Majumder et al. 2001; Abasi et al. 2011).

Nature's $\mathrm{N}$ management functioning within boundaries is meanwhile reasonably understood. Farmers use the new insights and try to approach within the functioning of nature's boundaries high biomass yields with monoculture crop plants and an adapted $\mathrm{N}$ management. Until the invention of technical $\mathrm{N}_{2}$ fixation (TNF) around 100 years ago, monoculture cropped plants suffered under N shortage; and for overcoming the $\mathrm{N}$ shortage, farmers selected better-adapted crops on fluctuating $\mathrm{N}$ sources and applied animal manure (Sturm et al. 1994; Lambers et al. 2011; Chen et al. 2013; Nacry et al. 2013). From 1908 to 1960 , the worldwide $\mathrm{N}$ inputs increased nine-fold and since then mobile $\mathrm{NO}_{3}{ }^{-}$ions reach increasingly the groundwater and $\mathrm{N}_{2} \mathrm{O}$ enriches in the atmosphere. Both, nitrate and $\mathrm{N}_{2} \mathrm{O}$ overloads generate enormous costs (Sutton et al. 2011). Ecologists, farmers, waste managers, and industries try meanwhile increasingly, scientifically and governmentally supported by having landscape conservation in the focus, to approach nature's evolutionary developed $\mathrm{N}$ overloads avoiding principles. Soil compaction minimizing tillage techniques are continually improved for achieving a better mixing of organic residues and inorganic soil components, a plant requirement-tuned mineral, animal manure and compost fertilization is practiced, intercropping with promising $\mathrm{N}_{2}$ fixing bacteria legume relationships is increasingly on the screen and a steadily developing petroleum saving, computerized precision farming that factors local differences is employed. Governmental organization platforms such as the Association of German Agricultural Research and Experimental Stations (VDLUFA) analyze periodically the nutrient contents in per hectare recommended animal manure amounts, which contain about 76, 19.2, 64.7, 33.6, 7.8, 0.1 kg N, P, K, Ca, Mg, and $\mathrm{Cu}$, respectively (Wiesler 1998). More reluctantly recommended is meanwhile the field application of sewage sludge, which may contain 3.8, 1.6, 0.4, 0.6, 5.3\% N, P, K, Mg, Ca and 202, 5, 131, 349, 53, 3, and $1446 \mathrm{mg} \mathrm{Pb}, \mathrm{Cd}, \mathrm{Cr}, \mathrm{Cu}, \mathrm{Ni}$, $\mathrm{Hg}, \mathrm{Zn}$ per $\mathrm{kg}$ dry matter, respectively (Benckiser and Simarmata 1994; Sturm et al. 1994; Fytili and Zabiotou 2008). Compost spreading rather recommended by the European Union (EU), is in the EU annually produced from about $300 \times 10^{6}$ tons of waste and spread on the 123,391 , 000 ha agri-, horti- and viniculturally used EU land (Barth et al. 2008; Beylich et al. 2010; PICCMAT 2011). Collected wastes generally consist of biowastes (5\%), green wastes (54\%), pre-digested products (30\%), sewage sludge, street litter, dead leaves, and industrial waste. Green wastes may contain hard or softwood bark, cardboard, corn stalks, grape pumice, hay from grass/lucerne, rough grass, round bales, green grass, olive pumice, paper newsprint, peat $\backslash$ moss, pine needles, pinewood shavings, sawdust, sawdust hardwood, straw from oat or wheat, shrub or tree trimmings, hard, soft woodchips or yard waste mixtures with single $\mathrm{CN}$ ratios of $125,135,520,40,27,25-95,70,400,64,110,350,365,996$, $120,55,120,30,430,500$, and 44, respectively, and produced composts out of such a material mix have $\mathrm{CN}$ and $\mathrm{C}_{\mathrm{H} 2 \mathrm{O}} / \mathrm{NO}_{3}{ }^{-}$ ratios of 15 and around 1000, respectively (Pauli and O’Malley 2008). Soil incorporated plant residues, composts, or biochar, a pyrolysed compost/animal manure mixture, recommended as soil ameliorators, improve the soil texture, enhance soil quality, health, and workability, sequester $\mathrm{CO}_{2}$, and reduce fossil fuel demand and erosion (Bouma 2014). They enrich soils with surplus reduction equivalents, dilute soil nitrate, and balance the $\mathrm{C}_{\mathrm{H} 2 \mathrm{O}} / \mathrm{NO}_{3}{ }^{-}$ratio in a way that the 
denitrifying communities are forced to use the electron acceptors $\mathrm{NO}_{3}^{-}, \mathrm{NO}_{2}^{-}, \mathrm{NO}$, and $\mathrm{N}_{2} \mathrm{O}$ economically. The result is a wider $\mathrm{N}_{2} / \mathrm{N}_{2} \mathrm{O}$ ratio (Tiedje 1988; Zumft 1997; Barth et al. 2008; Crutzen et al. 2008; Akiyama et al. 2010; Beylich et al. 2010; PICCMAT 2011; Chen et al. 2013; Fungo et al. 2014). $\mathrm{A} \mathrm{C}_{\mathrm{H} 2 \mathrm{O}} / \mathrm{NO}_{3}{ }^{-}$ratio balancing is easier achieved than with compost, plant residue or biochar incorporation with nitrification inhibitor-stabilized $\mathrm{N}$ fertilizers, which try to control directly nitrate formation especially during the plant's free and early growth period (Sturm et al. 1994; Zerulla et al. 2001). Because of less supplied nitrate, the emission of $\mathrm{N}_{2} \mathrm{O}$ is reduced and a wider $\mathrm{N}_{2} / \mathrm{N}_{2} \mathrm{O}$ ratio is achievable. Thus, an intensive searching for efficient nitrification inhibitors set in around 50 years ago (Mc Carty 1999) whereby heterocyclic, partly two or three adjacent $\mathrm{N}$ atoms and chlorine-containing, unsubstituted, $\mathrm{N}$ compounds as etridiazole (5-ethoxy-3trichloromethyl-1,2,4-thiadiazole, Dwell), 2-chloro-6trichloromethylpyridine (nitrapyrin), 3-mercapto-1,2,4-triazole, 4-amino-1,2,4-triazole, 3-methylpyrazole-1carboxamide or 2-ethinyl-pyridine, benzotriazole, 1,2,4-triazole, indazole, pyridazine, 3,4-dimethylpyrazole (DMP) were found to be effective (Kilian et al. 1998; Mc Carty 1999; Zerulla et al. 2001; Tindaon et al. 2012; Benckiser et al. 2013). As efficient nitrification inhibitors, chemicals as $\mathrm{N}$-allylthiourea, the $\mathrm{N}_{2} \mathrm{O}$ reductase blocking $\mathrm{C}_{2} \mathrm{H}_{2}$, dimethylether (DME), or dicyandiamide (DCD, $\mathrm{C}_{2} \mathrm{H}_{4} \mathrm{~N}_{4}$ ) were identified (Benckiser et al. 1986; Powell and Prosser 1986; Hallinger et al. 1990; Rajbanshi et al. 1992; Miller et al. 1993; Wagner et al. 1995; Bollmann and Conrad 1997; Philips et al. 2002; Li et al. 2008; de Klein et al. 2011; PICC MAT 2011; Eurostat yearbook, statistical guide to Europe, European Commission 2013). Each of these compounds aims to block the key enzyme of nitrification, the ammonium monooxygenase (AMO), whereby, e.g., dicyandiamide blocks the electron transport in the cytochromes of AMO during the conversion of $\mathrm{NH}_{3}$ to hydroxylamine or 3,4-dimethylpyrazole phosphate binds indiscriminately to the complex of membranebound proteins inclusively the AMO (Fig. 3). Dicyandiamide and 3,4-dimethylpyrazole phosphate have as nitrapyrin an AMO inhibition efficiency of more than $35 \%$, though their chemical structure is rather naturally than that of nitrapyrin and both seem not to affect non-target soil metabolisms at the recommended field application rates (Akiyama et al. 2010; Tindaon et al. 2012).

Dicyandiamide and 3,4-dimethylpyrazole phosphate are successfully marketed under the trade-names Alzon and Entec, respectively (PICCMAT 2011) and therefore this review tries to deduce from $\mathrm{N}_{2} \mathrm{O}$ formation studies in a compost pile, a municipal wastewater treatment plant, a constructed wetland and mineral, NI stabilized $\mathrm{N}$-fertilizer or sewage sludge amended soils possible $\mathrm{N}_{2} \mathrm{O}$ emission reducing ways in our industrializing world.

\section{$2 \mathrm{~N}_{2} \mathrm{O}$ formation in composting biowastes}

Compost companies as the Herhof Company, Giessen (http:// www.herhof.com/de/geschaeftsbereiche/trockenstabilat.html) receive municipal green biowastes differing in composition from delivery date to delivery date as the material brought on May 06 and May 13 display (May 06/May 13: green cutting $30-35 / 15 \%$, DM contents $54.4 / 41.4 \%$, total C $400 / 275$, total $\mathrm{N}$ 12.8/16.3 $\mathrm{g} \mathrm{kg}^{-1} \mathrm{DM}, \mathrm{C} / \mathrm{N}$ ratio 31.4/16.9, $\mathrm{pH}$ 6.4/6.7, $\mathrm{NH}_{4}{ }^{+}-\mathrm{N}, \mathrm{NO}_{3}{ }^{-}-\mathrm{N}, \mathrm{NO}_{2}{ }^{-}{ }^{-} \mathrm{N}$ and $\mathrm{C}_{\mathrm{H} 2 \mathrm{O}}$ contents $723 / 1293,26 /$ $142,2.0 / 4.9,10.1 / 12.5 \mathrm{mg} \mathrm{kg}^{-1} \mathrm{DM}$; for method details, see Benckiser et al. 1996). The May 06 biowaste, pre-composted in Herhoff Rotteboxes, where it was wetted around 7 to 10 days with recirculating seepage water until a temperature of about $65{ }^{\circ} \mathrm{C}$ was reached, was piled after being removed under the shelter of a front side open 15-m high halls to trapezoid, regularly turned around and wetted heaps (ca. $100 \times 4 \times 1.50 \mathrm{~m}$ ) over 10 weeks for reaching compost stabilization. Samples from the original and pre-composting material and stabilizing compost samples, weekly with an auger taken at ten different heap locations out of the heap depths of 0-5 and $50 \mathrm{~cm}$, were combined, separately per depth, mixed and in situ as 40-60-g proportions filled into airtight closable 250-ml flasks (Schott, Germany; three parallels). For driving out the $\mathrm{N}_{2} \mathrm{O}$ retained by the original, pre-composted, and stabilizing biowaste material, the airtight closed flasks were heated in a water bath $(80 \mathrm{~min}$ at $80{ }^{\circ} \mathrm{C}$ ) before in the flask headspace $\mathrm{N}_{2} \mathrm{O}$ was gaschromatographically determined and calculated in $\mathrm{mg} \mathrm{N}_{2} \mathrm{O}$ $\mathrm{N} \mathrm{kg}^{-1}$ compost DM (Weiske et al. 1995). The compost material pasteurization during the measuring procedure prevents a de novo $\mathrm{N}_{2} \mathrm{O}$ synthesis. In separate materials, ammonium, nitrate, nitrite, and $\mathrm{C}_{\mathrm{H} 2 \mathrm{O}}$ formation changes were analyzed.

$\mathrm{N}_{2} \mathrm{O}, \mathrm{NH}_{4}{ }^{+}, \mathrm{NO}_{2}^{-}, \mathrm{NO}_{3}^{-}$, and $\mathrm{C}_{\mathrm{H} 2 \mathrm{O}}$ formation in the biowaste and composting material was highest in the 6th week of compost stabilization (Fig. 5). Turning around the piled material assumingly favored $\mathrm{NO}_{3}{ }^{-}$and $\mathrm{N}_{2} \mathrm{O}$ formation where the upper $5 \mathrm{~cm}$ retained about $130.0 \pm 114.6 \mu \mathrm{g} \mathrm{N}_{2} \mathrm{O}-\mathrm{N} \mathrm{kg}^{-1}$ compost DM and the $50 \mathrm{~cm}$ heap depth material about 2844.0 $\pm 3988.1 \mu \mathrm{g} \mathrm{N} \mathrm{N}_{2} \mathrm{O}-\mathrm{N} \mathrm{kg}^{-1}$ compost DM. $\mathrm{N}_{2} \mathrm{O}$ formation was highly significant correlated with nitrite $(r=0.97)$, positive but not significant with nitrate and water-soluble carbon $(r=0.61$ and 0.55 , respectively). The high standard deviations indicate a spot-wise $\mathrm{N}_{2} \mathrm{O}$ formation.

\section{$3 \mathrm{~N}_{2} \mathrm{O}$-formation in and emission from municipal wastewater treatment plant}

$\mathrm{N}_{2} \mathrm{O}$ formation in a compost heap or in wastewater depends on temperature, $\mathrm{NH}_{4}{ }^{+}-\mathrm{N}, \mathrm{NO}_{3}{ }^{-}-\mathrm{N}, \mathrm{NO}_{2}{ }^{-}-\mathrm{N}$, and organic matter availability $\left(\mathrm{BOD}_{5}, \mathrm{COD}_{\mathrm{Mn}}\right)$. Consequently, in the aerated activated sludge $\left(1700 \mathrm{~m}^{3}\right.$; retention time $\left.120 \mathrm{~min}\right)$, the aerated nitrification unit, the non-aerated denitrification tank (16, 

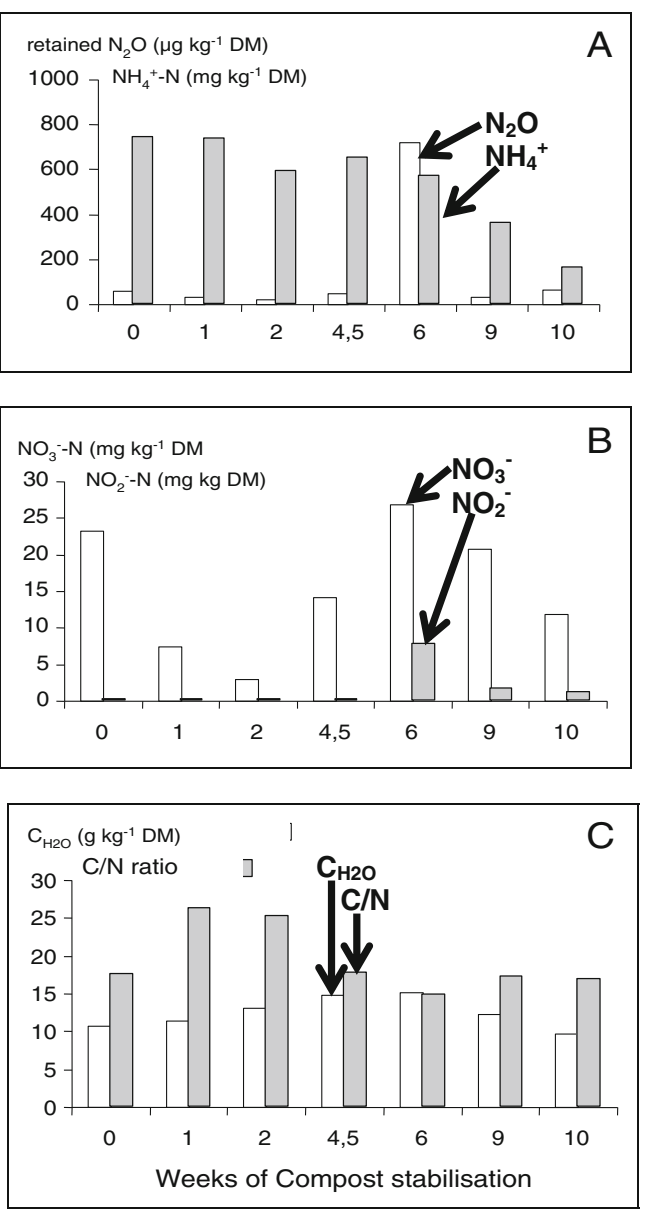

Fig. 5 Daily $\mathrm{N}_{2} \mathrm{O}$-surface fluxes (a acetylene inhibition technique) from a minerally fertilized $(a)$ or sewage sludge amended $(b)$ Parabrown earth (Inceptisol) planted to spring wheat during 1985 and compared with $\mathrm{N}_{2} \mathrm{O}$-production potentials in the soil depths $0-20,20-40$ and $40-60 \mathrm{~cm}$ (b and c)

$000 \mathrm{~m}^{3}$, retention time $140 \mathrm{~min}$ ) and the effluent of the municipal wastewater purifying plant in Giessen, Germany, dimensioned for about 150,000 inhabitants, $\mathrm{N}_{2} \mathrm{O}$ formation and emission in dependency of the above parameters were determined for getting an idea about reduction possibilities. In 40-ml wastewater samples regularly collected in $20 \mathrm{~cm}$ depth of each purification unit and the effluent and in situ filled into airtight closable 250-ml flasks (Schott, Germany), which were incubated in a water bath $\left(80^{\circ} \mathrm{C}, 80 \mathrm{~min}\right.$; Weiske et al. 1995) wastewaterretained $\mathrm{N}_{2} \mathrm{O}$ was determined. Emitting $\mathrm{N}_{2} \mathrm{O}$ was collected with self-constructed, open PVC covers $(60 \times 40 \times 20 \mathrm{~cm}$, four per unit), which had a perforated PVC-plate with 0.8 -cm-diameter holes fixed at the bottom for achieving a uniform membrane pump-driven and flow meter (Platon, Germany) controlled air flow of $90 \mathrm{~L} \mathrm{~h}^{-1}$ through each cover. The $\mathrm{N}_{2} \mathrm{O}$ separated air flow into a $20 \mathrm{~L} \mathrm{~h}^{-1}$ one that flew $2 \mathrm{~h}$ through silica gel and sodium hydroxide traps in order to remove $\mathrm{H}_{2} \mathrm{O}$ and $\mathrm{CO}_{2}$, and a glass column filled with $2 \mathrm{~mm}$ pellets of $0.5 \mathrm{~nm}$ molecular sieve to absorb the emitting $\mathrm{N}_{2} \mathrm{O}$ (Merck, Germany), and a bypassing $70 \mathrm{~L} \mathrm{~h}^{-1}$ one for preventing an uncontrolled cover up-floating in the air-bubbled purification tanks was gaschromatographically determined after desorption from the molecular sieve (Schwarz et al. 1994) and calculated in grams $\mathrm{N}_{2} \mathrm{O}-\mathrm{N}$ per day per tank or per effluent after having subtracted the $\mathrm{N}_{2} \mathrm{O}$ already present in the sucked through air. The wastewater-retained $\mathrm{N}_{2} \mathrm{O}$ was calculated in kilograms $\mathrm{N}_{2} \mathrm{O}-\mathrm{N}$ per day per tank or per effluent. For method details concerning $\mathrm{pH}$ and $\mathrm{N}$-, C-species $\left(\mathrm{N}_{\mathrm{t}}, \mathrm{NH}_{4}{ }^{+}-\mathrm{N}, \mathrm{NO}_{2}{ }^{-} \mathrm{N}, \mathrm{NO}_{3}{ }^{-} \mathrm{N}, \mathrm{C}_{\mathrm{t}}\right.$, $\mathrm{C}_{\mathrm{H} 2 \mathrm{O}}$ ) determination during the measuring periods March to July, 1994, November 1995 to March 1996, see Schwarz et al. (1994), Benckiser et al. (1996).

The mean water temperature, $\mathrm{pH}$ and $\mathrm{pO}_{2}$ of the introduced wastewater were during the March to July, 1994, period 9.6 $1{ }^{\circ} \mathrm{C}, 7.4 \pm 0.3$, and $6.4 \pm 0.6 \mathrm{mg} \mathrm{O}_{2} \mathrm{~L}^{-1}$, respectively, the $\mathrm{BOD}_{5}$ and $\mathrm{COD}_{\mathrm{Mn}} 170(10-510)$ and $196(32-756) \mathrm{mg} \mathrm{O}$ $\mathrm{L}^{-1}$, respectively, and $\mathrm{NH}_{4}{ }^{+}-\mathrm{N}, \mathrm{NO}_{3}{ }^{-}-\mathrm{N}$, and $\mathrm{NO}_{2}{ }^{-}-\mathrm{N} 28 \pm$ 3.4, $1.9 \pm 0.8$ and $0.5 \pm 0.4 \mathrm{mg} \mathrm{L}^{-1}$, respectively. The water temperature between November, 1995 and March, 1996 was $4.4 \pm 3{ }^{\circ} \mathrm{C}$, around $5{ }^{\circ} \mathrm{C}$ lower, and dependently the $\mathrm{NH}_{4}{ }^{+}-\mathrm{N}$, $\mathrm{BOD}_{5}$, and $\mathrm{COD}_{\mathrm{Mn}}$ in the aerated activated sludge unit $250 \%$ $\left(\mathrm{NH}_{4}{ }^{+}-\mathrm{N}, 70 \pm 40 \mathrm{mg} \mathrm{L}^{-1}\right), 170 \%\left(\mathrm{BOD}_{5}, 383 \pm 166 \mathrm{mg} \mathrm{O}_{2}\right.$ $\left.\mathrm{L}^{-1}\right)$, and $268 \%\left(\mathrm{COD}_{\mathrm{Mn}}, 527 \pm 314 \mathrm{O}_{2} \mathrm{~L}^{-1}\right)$ higher than in the March to July period. Similar during both measuring periods were $1.9 \pm 0.8$ or $1.9 \pm 1.4 \mathrm{mg} \mathrm{NO}_{3}^{-}-\mathrm{N} \mathrm{L}^{-1}$ and $0.5 \pm 0.4$ or 0.3 $\pm 0.23 \mathrm{mg} \mathrm{NO}_{2}^{-}-\mathrm{N} \mathrm{L}^{-1}$ for the nitrate and $\mathrm{NO}_{2}^{-}-\mathrm{N}$ concentration in the aerated activated sludge unit.

$\mathrm{NH}_{4}{ }^{+}-\mathrm{N}, \mathrm{NO}_{3}{ }^{-}-\mathrm{N}, \mathrm{NO}_{2}^{-}-\mathrm{N}, \mathrm{BOD}_{5}$, and $\mathrm{COD}_{\mathrm{Mn}}$ in the aerated nitrification tank $\left(>2 \mathrm{mg} \mathrm{O}_{2} \mathrm{~L}^{-1}\right)$ were in the March to July/November to March periods $3.1 \pm 0.9 / 6.3 \pm 8.2,3.3 \pm 1.2 /$ $1.8 \pm 1.3,0 / 0,0.07 \pm 0.05 / 0.07 \pm 0.05 \mathrm{mg} \mathrm{N} \mathrm{L}^{-1}$ or $1386 \pm 483 /$ $1987 \pm 799$, and $4549 \pm 2012 / 4247 \pm 1755 \mathrm{O}_{2} \mathrm{~L}^{-1}$, respectively, and in the unaerated denitrification tank $6.4 \pm 5.6 / 8.7 \pm 6.7,4.4$ $\pm 1.3 / 1.6 \pm 1.2,0 / 0.07 \pm 0.05 \mathrm{mg} \mathrm{N} \mathrm{L}^{-1}$ or $1534 \pm 297 / 1532 \pm$ 384 and $4560 \pm 1648 / 2846 \pm 863 \mathrm{mg} \mathrm{O}_{2} \mathrm{~L}^{-1}$, respectively. The corresponding March to July/November to March contents in the effluent were $0.4 \pm 0.15 / 5.4 \pm 4\left(\mathrm{NH}_{4}{ }^{+}-\mathrm{N}\right), 3.7 \pm 1.7 /$ $7.4 \pm 4\left(\mathrm{NO}_{3}{ }^{-}-\mathrm{N}\right), 0.1 \pm 0.1 / 0.18 \pm 0.11 \mathrm{mg} \mathrm{N} \mathrm{L}^{-1}\left(\mathrm{NO}_{2}{ }^{-} \mathrm{N}\right)$ or $33.5 \pm 22.8 / 10.9 \pm 9\left(\mathrm{BOD}_{5}\right)$, and $22.5 \pm 13 / 26 \pm 36 \mathrm{mg} \mathrm{O}_{2} \mathrm{~L}^{-1}$ $\left(\mathrm{COD}_{\mathrm{Mn}}\right)$, respectively.

Due to the prevailing environmental conditions, the $\mathrm{N}_{2} \mathrm{O}$ emissions from the aerated activated sludge and nitrification unit of the wastewater treatment plant, Giessen, were about 45 and 72 times higher, respectively, than the $\mathrm{N}_{2} \mathrm{O}$ emissions from the non-aerated denitrification tank, indicating that well-aerated wastewaters are a $\mathrm{N}_{2} \mathrm{O}$ source par excellence (Table 1). From the introduced $\mathrm{NH}_{4}{ }^{+}-\mathrm{N}$, roughly $1.56 \%$ left the wastewater treatment system of Giessen as $\mathrm{N}_{2} \mathrm{O}$ gas and about $1005 \mathrm{~kg} \mathrm{~N} \mathrm{~N}_{2} \mathrm{O}-\mathrm{N}$ in dissolved form with the purified wastewater. Probably because of different designs and operational conditions, nitrous oxide $\left(\mathrm{N}_{2} \mathrm{O}\right)$ emissions may substantially vary between wastewater treatment plants, ranging from negligible to substantial (a few percent of the total nitrogen load; Law et al. 2012). 
Table 1 Mean daily $\mathrm{N}_{2} \mathrm{O}$ emissions from different purifying units of the wastewater treatment plant, Giessen, compared with dissolved $\mathrm{N}_{2} \mathrm{O}$ amounts in the wastewaters ${ }^{\mathrm{a}}$

\begin{tabular}{|c|c|c|c|c|c|c|}
\hline \multirow[t]{2}{*}{ Purification tank } & \multicolumn{3}{|c|}{$\mathrm{N}_{2} \mathrm{O}$ emissions $\mathrm{g} \mathrm{N}_{2} \mathrm{O}-\mathrm{N}$ day $^{-1} \operatorname{tank}^{-1}$} & \multicolumn{3}{|c|}{$\begin{array}{l}\mathrm{N}_{2} \mathrm{O} \text { dissolved in the wastewater } \mathrm{kg} \mathrm{N}_{2} \mathrm{O}-\mathrm{N} \text { day } \\
\text { or effluent }^{-1}\end{array}$} \\
\hline & $\begin{array}{l}\text { March 1993- } \\
\text { March } 1994\end{array}$ & $\begin{array}{c}\text { March } 1994- \\
\text { July } 1994\end{array}$ & $\begin{array}{l}\text { November 1995- } \\
\text { March } 1996\end{array}$ & $\begin{array}{l}\text { March 1993- } \\
\text { March } 1994\end{array}$ & $\begin{array}{c}\text { March } 1994 \\
\text { July } 1994\end{array}$ & $\begin{array}{l}\text { November } 1995- \\
\text { March } 1996\end{array}$ \\
\hline Activated sludge $^{\mathrm{b}}$ & $10.4 \pm 13.2$ & $5.9 \pm 2.9$ & $7.7 \pm 5.4$ & n.d. & n.d. & n.d. \\
\hline Nitrification unit ${ }^{\mathrm{a}, \mathrm{b}}$ & n.d. ${ }^{\mathrm{c}}$ & $936 \pm 1354$ & $46 \pm 17.3$ & n.d. & $0.8 \pm 0.42$ & $23.1 \pm 13.1$ \\
\hline Denitrifyca-tion unit ${ }^{\mathrm{b}}$ & n.d. & $14.4 \pm 17.3$ & $7.1 \pm 3.5$ & n.d. & $0.52 \pm 0.25$ & $6.1 \pm 5.2$ \\
\hline Effluent $^{\mathrm{b}}$ & n.d. & n.d. & $3.0 \pm 5.8$ & & & $6.7 \pm 2.5$ \\
\hline
\end{tabular}

${ }^{a}$ About 150,000 inhabitants deliver their wastewater to the municipal wastewater treatment plant of Giessen, Germany, and this inflowing wastewater has a mean $\mathrm{BOD}_{5}$ of $170(10-510) \mathrm{mg} \mathrm{L}{ }^{-1}$, a COD of $196(32-756) \mathrm{mg} \mathrm{O}_{2} \mathrm{~L}^{-1}$, and $\mathrm{NH}_{4}^{+}{ }^{-} \mathrm{N}^{-}$and $\mathrm{NO}_{3}^{-}-\mathrm{N}^{-}$contents of $33(5.7-52)$ and $2.5(0.3-$ $13.8 \mathrm{mg} \mathrm{L}^{-1}$ ), respectively

${ }^{\mathrm{b}}$ The total volumes of the activated sludge-, nitrification- and denitrification tanks were $2080,11,000$, and $11,000 \mathrm{~m}^{3}$, respectively. The daily effluent of purified wastewater amounted to $52,000 \mathrm{~m}^{3}$ and the surface area of the discharging channel was $416 \mathrm{~m}^{2}$

${ }^{\mathrm{c}}$ n.d. not determined

\section{$4 \mathrm{~N}_{2} \mathrm{O}$ formation and emission from a constructed wetland}

Constructed wetlands, generally having a ground filter, filled with a sandy loam soil peat mixture and planted with reed increasingly purify the wastewater of less populated areas (Leverenz et al. 2010). We were interested in how such wastewater-treating systems work during the winter period when low temperatures interrupt the growth of the ground filter oxygenating reed plants. With an auger, we collected between October 1994 and April 1995 in the 0-20, 20-40, and 40-60 cm soil depth reed bed samples (center and close to the in- and outlet) and quantified $\mathrm{COD}, \mathrm{BOD}_{5} \mathrm{C}_{\mathrm{H} 2 \mathrm{O}}$, ammonium, nitrate, nitrite, retained, and emitted $\mathrm{N}_{2} \mathrm{O}$ at a soil temperature of around $+3{ }^{\circ} \mathrm{C}$, lowest $1^{\circ} \mathrm{C}$ below the freezing point in the $10 \mathrm{~cm}$ ground filter depth and of around $+5,8^{\circ} \mathrm{C}$, lowest $+2{ }^{\circ} \mathrm{C}$ in the $50 \mathrm{~cm}$ ground filter depth (groundfilter, for method and result details, see Fey et al. 1999).

Briefly, $\mathrm{N}_{2} \mathrm{O}$, retained by the $0-20 \mathrm{~cm}$ reed bed layer of the constructed wetland, Friedelhausen, Germany $\left(\mathrm{C}_{\mathrm{H} 2 \mathrm{O}} / \mathrm{NO}_{3}{ }^{-}\right.$ratio 32.1 ; temperatures between -1 and $+5.8{ }^{\circ} \mathrm{C}$ ) that received farm wastewater was about three times more than the $\mathrm{N}_{2} \mathrm{O}$, retained by the $50 \mathrm{~cm}$ ground filter zone $\left(\mathrm{C}_{\mathrm{H} 2 \mathrm{O}} / \mathrm{NO}_{3}{ }^{-}\right.$ratio 54.8). $\mathrm{BOD}_{5}$ and $\mathrm{COD}_{\mathrm{Mn}}$ degradation during the same period were 78.2 and $49.4 \%$. From the around $159 \mathrm{~kg} \mathrm{~N}$, the ground filter received during the winter period, around $177 \mathrm{~g}$ or $0.11 \%$ was emitted as $\mathrm{N}_{2} \mathrm{O}-\mathrm{N}$ and $0.02 \%$ retained by the ground filter.

\section{Actual and potential denitrification in sewage sludge and/or mineral fertilized Parabrown earth field plots}

Actual denitrification measurements provide information about gaseous $\mathrm{N}$ surface losses and their atmospheric interactions, while potential denitrification capacity (PDC) quantifications inform about the influence of available carbon on the denitrification process (Burford and Bremner 1975). In both sources of information about denitrification, in 1985, we quantified $\mathrm{N}_{2} \mathrm{O}$ in only minerally fertilized and with liquid municipal sewage sludge amended Inceptisol (Parabrown earth) field plots (44.7\% sand, $47.2 \%$ silt, and $8.1 \%$ clay; pH of 6.8 in the upper $20 \mathrm{~cm}$, bulk density $1.52 \mathrm{~g} \mathrm{~cm}^{-3}$, pore volume $43.5 \%$, silty sand) at the Federal Research Center of Agriculture, Braunschweig, Germany, with the acetylene inhibition technique $\left(\mathrm{N}_{2} \mathrm{O}+\mathrm{N}_{2}\right)$. The sewage sludge-amended field received $3500 \mathrm{~m}^{3} \mathrm{ha}^{-1}$ liquid municipal sludge (CN ratio about 10; $620 \mathrm{~kg} \mathrm{~N}, 260 \mathrm{~kg} \mathrm{P}$, and $40 \mathrm{~kg} \mathrm{~K}$ ) in 1971 and from 1980 until the experimental year 1985 annually $300 \mathrm{~m}^{3} \mathrm{ha}^{-1}$. In auger-collected 40-g Inceptisol samples out of the soil depths of $0-20,20-40$, and 40-60 $\mathrm{cm}$ of each experimental field plot, which were in situ filled into dark serum bottles (120 ml; 3 replicates), PDC was quantified. To each bottle $10 \mathrm{ml} \mathrm{H}_{2} \mathrm{O}$ was added for approximating a maximal water holding capacity of about $200 \%$ and a $\mathrm{KNO}_{3}$ solution to have a final $\mathrm{N}$-content of $100 \mu \mathrm{g} \mathrm{NO}_{3}{ }^{-} \mathrm{N} \mathrm{g}^{-1}$ soil. The atmosphere of the airtight-closed flasks was replaced by helium and $5 \mathrm{ml}$ $\mathrm{C}_{2} \mathrm{H}_{2}$ and after a 48-h incubation the emitting $\mathrm{N}_{2} \mathrm{O}$ was expressed in kilograms $\mathrm{N}_{2} \mathrm{O}-\mathrm{N}$ per ha ${ }^{-1}$ (for further details, see Benckiser et al. 1987).

Figure 6, comparing $\mathrm{N}_{2} \mathrm{O}$ surface fluxes and PDC values, unveils that the PDC-related $\mathrm{N}_{2} \mathrm{O}$ formation in the $40-60 \mathrm{~cm}$ soil layer of the only minerally fertilized field plots (Fig. 6b), which was about five times less than in the sewage sludgeamended ones (Fig. 6c), surpassed the $\mathrm{N}_{2} \mathrm{O}-\mathrm{N}\left(\mathrm{N}_{2} \mathrm{O}+\mathrm{N}_{2}\right)$ surface fluxes (Fig. 6a) and indicates that under the prevailing minerally $\mathrm{N}$ fertilized conditions, carbon, rather than the nitrate availability, seems to limit denitrification. The high standard deviations of the emitted $\mathrm{N}_{2} \mathrm{O}$ parallels (Fig. 6a) suggest the compost pile (Fig. 5), wastewater plant (Table 1), and the constructed wetland measurements (Fey et al. 1999) hot spot denitrification. About 5 to $10 \%$ of the added mineral 
$\mathrm{g} \mathrm{N}_{2} \mathrm{O}-\mathrm{N} \mathrm{ha}^{-1}$ day $^{-1}$
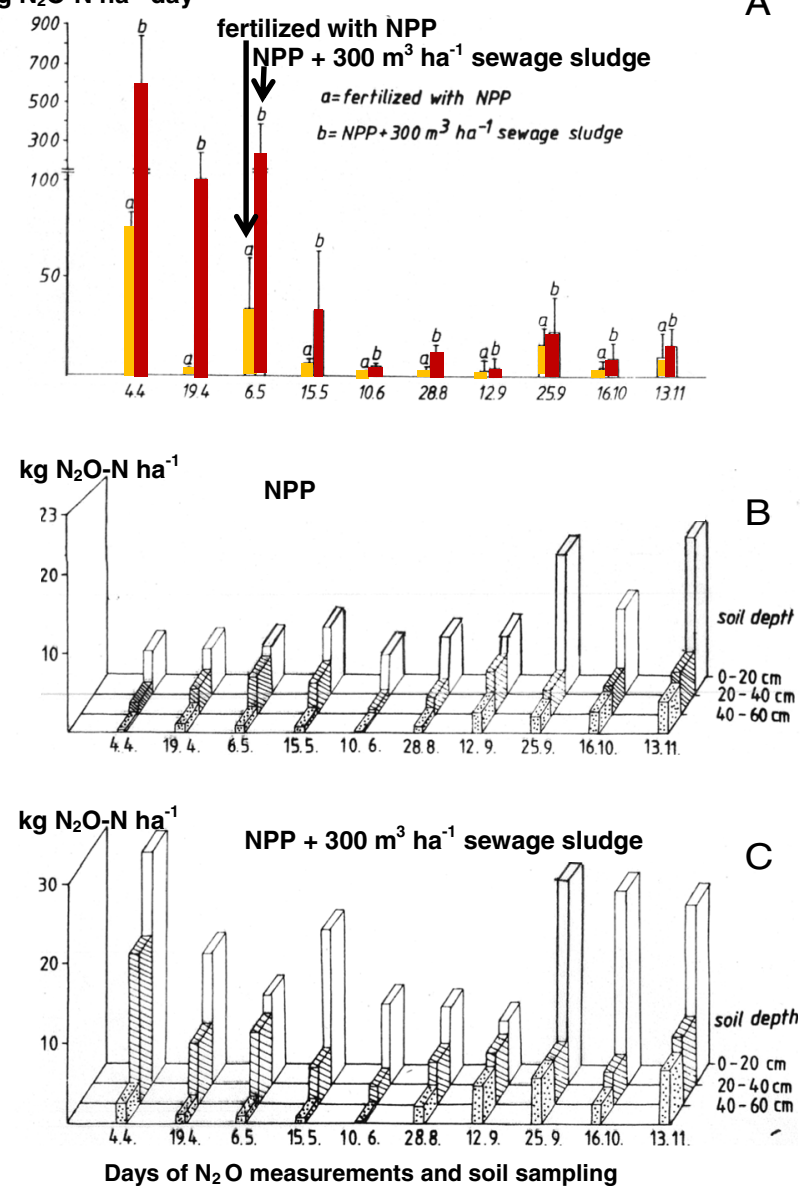

Fig. 6 Daily acetylene inhibition technique measured $\mathrm{N}_{2} \mathrm{O}$-surface fluxes from minerally and/or sewage sludge amended Parabrown earth (Inceptisol) field plots, planted to spring wheat during 1985 (a) in comparison to potential $\mathrm{N}_{2} \mathrm{O}$-production in the soil depths of $0-20,20$ 40 and $40-60 \mathrm{~cm}(\mathbf{b}$ and $\mathbf{c})$

fertilizer $\mathrm{N}$ to the Inceptisol soil was lost as emitted $\mathrm{N}_{2} \mathrm{O}$. Though it is meanwhile well known that gaseous $\mathrm{N}$ loss estimates with the acetylene inhibition technique are questionable, because $\mathrm{C}_{2} \mathrm{H}_{2}$ not only blocks the $\mathrm{N}_{2} \mathrm{O}$-reductase but also impairs the nitrification process and favors $\mathrm{NO}_{2}$ formation (Bollmann and Conrad 1997), measurements with this technique provide at least hints which of the denitrification determining parameters need to be controlled when a $\mathrm{N}_{2} \mathrm{O}$ emission reduction is aimed. Very recent slurry spreading experiments with different application techniques to field soils differing in clay, silt organic matter contents, $\mathrm{pH}$, bulk density, and water content at field capacity revealed that broadcast spreading favors $\mathrm{NH}_{3}$ emission and slurry injection in the release of $\mathrm{N}_{2} \mathrm{O}$ (Langevin et al. 2014). Sewage sludge spreading in such high amounts on agricultural fields, even deployed with sophisticated techniques, is nowadays less tolerated, especially when greenhouse gas emissions shall be kept in a tolerable range.

\section{Nitrification inhibitor effects on $\mathrm{N}_{2} \mathrm{O}$ emissions from wastewater and soil}

In wastewater, liter-wise sampled on March 02, 1996, in different depths of the earlier mentioned units of the wastewater treatment plant, Giessen, Germany, which were thoroughly mixed and in 200-ml subsamples filled in airtight closable $500-\mathrm{ml}$ flasks (six replicates of each unit), to which $30 \mathrm{mg}$ nitrate $\mathrm{L}^{-1}$ as $\mathrm{KNO}_{3}$ was added before the liquid culture nitrification inhibiting efficiency of nitrapyrin, allylthiourea, dimethylether, and 3,4-dimethylpyrazole phosphate were tested. Nitrapyrin and allylthiourea were added in a concentration of $5 \mathrm{mg} \mathrm{L}^{-1}$ (Powell and Prosser 1986; Wagner et al. 1995), dimethylether in a concentration of $25 \%(v / v$; Miller et al. 1993) and 3,4-dimethylpyrazole phosphate in a concentration of $0.01 \mathrm{mg} \mathrm{L}^{-1}$ wastewater (Weiske et al. 2001). After inhibitor addition, the flasks were airtight closed (dimethylether was added to the airtight-closed flasks) and incubated. Nitrapyrin and dimethylether effects were only studied in activated sludge wastewater and are reported in the text, while allylthiourea and 3,4-dimethylpyrazole phosphate effects are shown in Fig. 7. The mean initial headspace $\mathrm{pO}_{2}$ of all flasks was $460 \mathrm{mg} \mathrm{O}_{2} \mathrm{~L}^{-1}$.

The used activated sludge wastewater had a $\mathrm{BOD}_{5}$ and $\mathrm{COD}_{\mathrm{Mn}}$ of 1629 and $3498 \mathrm{O}_{2} \mathrm{~L}^{-1}$ and contained 19.9, 4.75, $0.01 \mathrm{mg} \mathrm{NH}{ }^{+}-, \mathrm{NO}_{3}^{-}-, \mathrm{NO}_{2}^{-}-\mathrm{N} \mathrm{L}^{-1}$, the nitrification tank

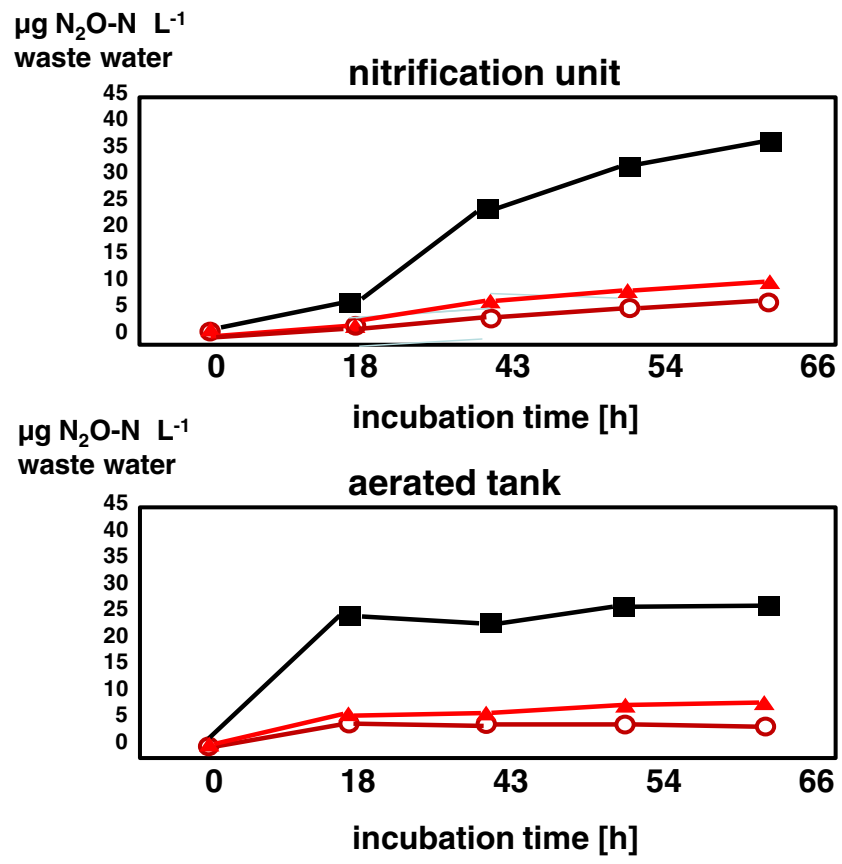

Fig. 7 Nitrification inhibitor 3,4 dimethylpyrazolephosphate and Nallylthiourea added in a concentration of 1 or $5 \mathrm{mg} \mathrm{L}^{-1}$ to waste water collected on March 02, 1996, in the aerated nitrification unit and activated sludge tank, public waste water treatment plant Giessen, Germany, in comparison to controls without the addition of nitrification inhibitors. The initial flask headspace $\mathrm{pO}_{2}$ was $460 \mathrm{mg} \mathrm{O}_{2} \mathrm{~L}^{-1}$ 
wastewater $\mathrm{B} \mathrm{BOD}_{5}$ and $\mathrm{COD}_{\mathrm{Mn}}$ of 1386 and $4549 \mathrm{O}_{2} \mathrm{~L}^{-1}$ and

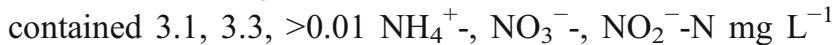
(analysis, Benckiser et al. 1996). The driven out $\mathrm{N}_{2} \mathrm{O}$ after five incubation days (water bath: $80{ }^{\circ} \mathrm{C} ; 80 \mathrm{~min}$; Weiske et al. 1995) was, as $\mathrm{O}_{2}$, gas-chromatographically analysed and expressed in milligrams $\mathrm{N}_{2} \mathrm{O}-\mathrm{N}$ per liter wastewater.

The mean flask headspace $p \mathrm{O}_{2}$ declined from $460 \mathrm{mg}$ $\mathrm{O}_{2} \mathrm{~L}^{-1}$ to $33 \pm 1.87 \mathrm{mg} \mathrm{O}_{2} \mathrm{~L}^{-1}$ and the emitted $\mathrm{N}_{2} \mathrm{O}$ in the presence of nitrapyrin and dimethylether was 97.1 or $97.3 \%$ lower $\left(51 \pm 9\right.$ without/ $1.5 \pm 0.4 \mathrm{mg} \mathrm{N} 2 \mathrm{O}-\mathrm{N} \mathrm{L}^{-1} \times 100$ with nitrapyrin or $51 \pm 14$ without $/ 1.4 \pm 0.6 \mathrm{mg} \mathrm{N}_{2} \mathrm{O}-\mathrm{N} \mathrm{L}^{-1} \times 100$ with dimethylether). Similar effects showed 3,4dimethylpyrazole phosphate and N-allylthiourea (Fig. 7). In summary, all four tested nitrification inhibitors exhibited as promising $\mathrm{N}_{2} \mathrm{O}$ formation reducing candidates under liquid (wastewater) conditions.

Under soil conditions, the AMO inhibiting efficiency of 3, 4-dimethylpyrazole phosphate and dicyandiamide was tested in a 3-year agricultural field experiment, in which ASN-N fertilized spring barley, Hordeum vulgare $\mathrm{L}\left(90 \mathrm{~kg} \mathrm{~N} \mathrm{ha}^{-1}\right)$, maize, Zea mays L. (160 $\left.\mathrm{kg} \mathrm{N}^{-1}\right)$, and winter wheat, Triticum aestivum L.(180 kg N ha $\left.{ }^{-1}\right)$ plots $(26 \% \mathrm{~N}, 18.5 \%$ $\mathrm{NH}_{4}{ }^{+}-\mathrm{N}$ and $\left.7.5 \% \mathrm{NO}_{3}{ }^{-}-\mathrm{N}\right)$ were compared with plots having received DMPP and DCD ASN-N-stabilized fertilizers (DCD: $16 \%$ to $\mathrm{NH}_{4}{ }^{+}-\mathrm{N}$; DMPP: $1.6 \%$ to $\mathrm{NH}_{4}{ }^{+}-\mathrm{N}$ ). The trace gas emissions $\left(\mathrm{CO}_{2}, \mathrm{CH}_{4}\right.$, and $\left.\mathrm{N}_{2} \mathrm{O}\right)$, converted into $\mathrm{CO}_{2}$-equivalents (Table 2) were evaluated by the closedchamber method (Weiske et al. 2001). Besides plant growth, soil parameters and the disappearance of 3,4dimethylpyrazole phosphate and dicyandiamide were measured (for method details see Rajbanshi et al. 1992; Weiske et al. 2001; Benckiser et al. 2013).

In the presence of dicyandiamide and 3,4-dimethylpyrazole phosphate, the emission of $\mathrm{N}_{2} \mathrm{O}$ was reduced by 25.8 and $48.7 \%$, respectively, and was, in field soil, compared to the $\mathrm{N}_{2} \mathrm{O}$ reduction efficiency of nitrification inhibitors (NI) in liquid culture (Fig. 7), considerably lower (Table 2). NI diffusion and adsorption phenomena in soils certainly more distinct than in wastewater may explain the inhibition efficiency

Table 2 Influence of the nitrification inhibitors 3,4-dimethylpyrazole phosphate $(D M P P)$ and dicyandiamide $(D C D)$ control on the $\mathrm{CO}_{2}, \mathrm{CH}_{4}$ and $\mathrm{N}_{2} \mathrm{O}$ emissions and the global warming potential caused by the DMPP treated summer barley (1997), corn (1998) and winter wheat (1999) cropped plots in comparison to control plots, which never have seen DMPP. For the database see Weiske et al. (2001)

\begin{tabular}{lllll}
\hline & $\begin{array}{l}\Sigma \mathrm{g} \mathrm{CO}_{2} \mathrm{C} \\
\mathrm{ha}^{-1} \mathrm{day}^{-1}\end{array}$ & $\begin{array}{l}\Sigma \mathrm{g} \mathrm{CH}_{4} \mathrm{C} \\
\mathrm{ha}^{-1} \mathrm{day}^{-1}\end{array}$ & $\begin{array}{l}\Sigma \mathrm{g} \mathrm{N}_{2} \\
\mathrm{O}-\mathrm{N} \mathrm{ha}^{-1} \mathrm{day}^{-1}\end{array}$ & $\mathrm{CO}_{2}$-equivalents \\
\hline Control & 5840594 & -130 & 828 & $6094553(100 \%)$ \\
DCD & 5456339 & -130 & 614 & $5643788(93 \%)$ \\
DMPP & 4185470 & -166 & 425 & $4313752(70 \%)$ \\
\hline
\end{tabular}

${ }^{\mathrm{a}} \mathrm{CO}_{2}+\left(\mathrm{CH}_{4} \times 21\right)+\left(\mathrm{N}_{2} \mathrm{O} \times 310\right)$ difference. Fortunately, not affected was the AMO resembling mono methane oxidase (MMO) by DMPP and DCD, indicating a high inhibition specificity of both NI. Nevertheless, the observed $\mathrm{CO}_{2}$ emission decline in the presence of DMPP $(28.3 \%)$ and DCD (6.6\%; Table 2$)$ is presently not understood.

\section{$7 \mathrm{CN}$ ratio-dependent $\mathrm{N}_{2} \mathrm{O}$ emissions}

In addition to the nearly annually and globally produced 4 billion metric tons of crop residues, which are incorporated into agricultural land or burnt on fields, carbon sequestration favoring, soil fertility ameliorating composts, and animal manures with varying $\mathrm{CN}$ ratios are spread and all these organic amendments shift the electron donator/electron acceptor ratio $\left(\mathrm{C}_{\mathrm{H} 2 \mathrm{O}} / \mathrm{NO}_{3}{ }^{-}\right.$ratio) towards electron surplus. Sewage sludge spreading on fields is nowadays less recommended; rather, what is recommended is the addition of sewage sludge to biogas plants, or its deposition in waste dumps, or making compost out of it. Under natural conditions, only 0.1 to $2 \%$ of the microbial soil community seem to be continually active but when soils are organic amended, substrate is added and their activity can increase within minutes to around $40 \%$ (Blagodatskaya and Kuzyakov 2013). Dormant microbial cells in contrast need several days before their activity regains, because at this living status, nutrient availability to the producer cell enzymes determines the transition length from the dormant to the active status. Substrate turnover and cycling through the food web and chemical, physical, and biological soil properties changes are thereby also of relevance (Huang et al. 2004; Klemedtsson et al. 2005; Lal 2005; Toma and Hatano 2007; Steffen et al. 2011; Blagodatskaya and Kuzyakov 2013; Burns et al. 2013).

A low $\mathrm{NO}_{3}{ }^{-}$availability at electron surplus (Figs. 5, 6, 7, and 8) forces the denitrifying community to reduce under such circumstances also $\mathrm{N}_{2} \mathrm{O}$ efficiently to $\mathrm{N}_{2}$ (Fig. 8). Plant residues have a $\mathrm{CN}$ ratio spectrum from 8 to 118 (Huang et al. 2004). If residues with a $\mathrm{CN}$ ratio $>75$ are incorporated into soils then it is observed that less $\mathrm{N}_{2} \mathrm{O}$ and $\mathrm{CO}_{2}$ are emitted, because of an assumed protein- $\mathrm{N}$ complexation and polyphenol $\mathrm{N}$ immobilization. The low $\mathrm{N}_{2} \mathrm{O}$ emissions from forested histosol sites substantiate this observation (Klemedtsson et al. 2005; Zhang et al. 2011). A soil CN ratio above ca. 30, shaped by factors as climate, $\mathrm{pH}$, groundwater tables, oxygen depletion, carbon availability, to mention a few, is threshold for net $\mathrm{N}$ immobilization. Incorporated onion leaf, soybean stem and leaf, rice, and wheat straw residues of 11.6, 14.5, 62.3, and $110 \mathrm{CN}$ ratios, respectively, into Gray Lowland soil, Mikasa, Hokkaido, Japan, exhibited, as also found by Bremner and Blackmer (1981), a negative correlation between residue CN ratio and the emission of $\mathrm{N}_{2} \mathrm{O}$ (Toma and Hatano 2007). Organic residue amendments plus urea placement lead to 
$\% \mathrm{~N}_{2}$ (denitrification)

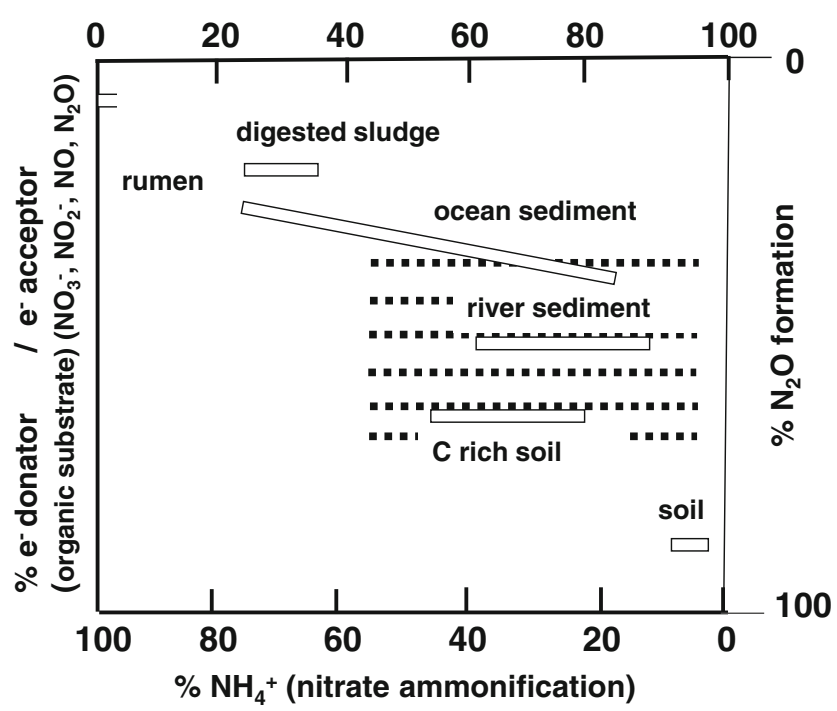

Fig. 8 Terrestrial and aquatic, energy gaining nitrate reduction processes in dependency of the electron donator ((easy available carbon)/acceptor (nitrate) ratio (adapted from Poth and Focht 1985; Poth 1986; Tiedje 1988; Benckiser 1997; Strous et al. 1997; Philips et al. 2002; Strohm et al. 2007)). $\mathrm{N}_{2}$ formation and nitrate ammonification occur preferred in biotops with electron surplus (rumen, digested sludge, rhizosphere), less in only minerally (NO3-) fertilized soils

uneven nutrients distributions. Nitrification inhibitors tentatively enhance this effect and spot-wise nitrification (Azam et al. 2001). A negative correlation between $\mathrm{N}_{2} \mathrm{O} / \mathrm{NO}_{3}{ }^{-}$and residue $\mathrm{CN}$ ratio is favored (Bremner and Blackmer 1981; Benckiser 1997; Klemedtsson et al. 2005; Chen et al. 2013; $\mathrm{Xu}$ et al. 2014). Urea combined with low $\mathrm{CN}$ ratio organic residues fertilization (CN ratio below 15-20) stimulates the activity of chemolithotrophic, urease producing, and ammonia oxidizing bacteria. The soil nitrate concentration increases. The less economically working denitrifying community will prefer to release $\mathrm{N}_{2} \mathrm{O}$ instead of $\mathrm{N}_{2}$ (Fig. 7; Huang et al. 2004; Koper et al. 2004; Chen et al. 2013). All these dependencies make the prediction of $\mathrm{N}_{2} \mathrm{O}$ emissions not easy. Low in nitrate but rich in sun-energized electrons are present in terrestrial ecosystems rhizospheres, such as anaerobically functioning grass-fed rumens, earthworm guts or soil crumbs after residue incorporation. Such carbon surplus environments exemplify par excellence the $\mathrm{CN}$ ratio influence on $\mathrm{N}_{2} \mathrm{O}$ emissions and where available $\mathrm{NO}_{3}{ }^{-}$may even be reduced to $\mathrm{NH}_{3}$ (Figs. 1 and 8). In soil zones enriched with nitrate by nitrification or fertilization, much of the produced $\mathrm{N}_{2} \mathrm{O}$ escapes after rainfall events from the cell membranes and reach the surrounding atmosphere before it is reduced to $\mathrm{N}_{2}$ (Fig. 8; Hungate 1966; Depkat-Jakob et al. 2010; Carvalhais et al. 2011; Fungo et al. 2014). Once $\mathrm{N}_{2} \mathrm{O}$ reached the atmosphere, a reduction to $\mathrm{N}_{2}$ could be possible but is unlikely (Vieten et al. 2008; Chen et al. 2013). The difficulties in predicting nitrification-denitrification events, in predicting $\mathrm{N}_{2} \mathrm{O}$ emission, also the soil mosaic formation of well and less aerated, well and less organically enriched patches, created by long-term environmental drivers as climate, plant exudation, soil animal activity, microbial and fertilizer $\mathrm{N}$ inputs, $\mathrm{O}_{2}$ diffusion, or ammonium fixation by biomass and clay-humus complexes, soil texture changes, root-hyphae effects, the fact that in air-, water-filled soil pores aerobic, anaerobic respiration, and fermentation occur in close neighborhood, the steadily varying $\mathrm{C}_{\mathrm{H} 2 \mathrm{O}} / \mathrm{NH}_{4}^{+} /$ $\mathrm{NO}_{3}{ }^{-}$ratios contribute and make the modeling of N-cycling a challenge (Fig. 8; Scherer 1993; Syring and Benckiser 1990; Benckiser 1997; Taroncher-Oldenburg et al. 2003; Huang et al. 2004; Wallensten et al. 2006; Henry et al. 2008; Benckiser 2010; Carvalhais et al. 2011; Benckiser and Bamforth 2011; Hangs et al. 2013). During Earth's genesis, plants have learnt to attract inorganic nutrients extracting and $\mathrm{N}$ supplying microbes by phloem exudation and this strategy helped to adapt on fluctuating $\mathrm{N}$ availabilities (Nacry et al. 2013). Ruminants have learnt to select among grassland plants and tried to avoid those containing nitrate $<1 \%$ per dry weight, because ruminants' mouth/rumen microflora reduces nitrate mostly only to $\mathrm{NO}_{2}{ }^{-}$that causes chronic nitrite intoxication and not further to NO, nitrosamines (RN-NO), $\mathrm{N}_{2} \mathrm{O}$, and $\mathrm{N}_{2}$ (Purcell et al. 1971; Braker et al. 2012).

\section{Denitrification strategies}

The denitrification forerunner, nitrification, converts fertilized $\mathrm{NH}_{4}{ }^{+}$to $\mathrm{NO}_{3}{ }^{-}$by consuming $\mathrm{O}_{2}$ (Fig. 2). If $\mathrm{O}_{2}$ is consumed and sufficient $\mathrm{C}_{\mathrm{H} 2 \mathrm{O}}$ (electron donors) is available, denitrifying communities reduce nitrate to $\mathrm{NO}_{2}^{-}, \mathrm{NO}, \mathrm{N}_{2} \mathrm{O}$ preferred to $\mathrm{N}_{2}$ (Zumft 1997). At each $\mathrm{NH}_{4}^{+}$oxidation and reduction step, energy is conserved, under optimal growth and denitrifying conditions per mole of glucose up to $90 \%$ of the energy (ATP) obtainable by $\mathrm{O}_{2}$ respiration (Figs. 1 and 2; Burth et al. 1982; Zumft 1997; Cabello et al. 2004; Zhang et al. 2011; Braker et al. 2012). A key enzyme is the nitrite reductase of which two forms exist. In the same bacterial strain, only one of these two nitrite reductases is present, either the nir S gene encoded cytochrome $c d_{l}$ or the non-heme copper-dependent nirK and nosZ gene encoded nitrite reductase. Ammonia oxidizing bacteria, for example, possess a nirK-encoded nitrite reductase, while $\mathrm{N}_{2} \mathrm{O}$-emitting denitrifiers or halobenzoate degraders possess a nirS-gene encoded nitrite reductase. Bacterial species as $E$. coli, a well-known representative among intestinal bacteria, and some of the archaea reduce $\mathrm{NO}_{3}{ }^{-}$only to $\mathrm{NO}_{2}{ }^{-}$, the key role player in heterotrophic nitrifiers' denitrification or nitrate ammonification (Figs. 3 and 8). Microorganism and $\mathrm{C}_{\mathrm{H} 2 \mathrm{O}}$-dependent $\mathrm{NO}_{2}{ }^{-}$is further reduced to $\mathrm{NO}$ and the greenhouse gas $\mathrm{N}_{2} \mathrm{O}$ (Fig. 1). If $\mathrm{N}_{2} \mathrm{O}$ escaped from the cell membrane and entered earth's atmosphere only in traces, it will be further reduced to $\mathrm{N}_{2}$ (Vieten et al. 2008); and in holding $\mathrm{N}_{2} \mathrm{O}$ on the membrane, the element ruthenium $(\mathrm{Ru})$ seemingly 
plays a crucial role $\left(\left[(\mathrm{RU})\left(\mathrm{NH}_{3}\right)_{5}\left(\mathrm{~N}_{2} \mathrm{O}\right)\right]^{2+}\right.$ (Zumft 1997; Fungo et al. 2014). $\mathrm{Ru}$ is like iron and copper, a d-block element in denitrification enzymes, and may at least partly explain why in soil biochar experiments the $\mathrm{N}_{2} \mathrm{O}$ emission reduction varied between 10 and $41 \%$.

The highly mobile nitrate ion, if not taken up by plants or denitrified to $\mathrm{N}_{2} \mathrm{O}$ and $\mathrm{N}_{2}$, will reach the ground (drinking) water and may cause health problems. If it is reduced to $\mathrm{N}_{2} \mathrm{O}$, it is an atmosphere-threatening 300-times-more-potent greenhouse gas than $\mathrm{CO}_{2}$ and an ozone-layer depleter (Michel and Wozniak 1998; Crutzen et al. 2008). Thus, it is of general interest to keep the formation of both compounds in an acceptable range all the more because presently, annual costs of around 100 billion US dollars caused by $\mathrm{NO}_{3}{ }^{-}$and $\mathrm{N}_{2} \mathrm{O}$ needs to be avoided (Ravishankara et al. 2009; Steffen et al. 2011; Sutton et al. 2011). Increasingly identified as $\mathrm{N}_{2} \mathrm{O}$ and $\mathrm{CH}_{4}$ emission sources are converted primary forests and permafrost soils, and ecologists have started to think about how ecosystem-change-related greenhouse gas emissions can be slowed in their magnitude. Also, turned around compost heaps and aerated wastewaters emit $\mathrm{N}_{2} \mathrm{O}$ and force waste managers to think in a similar direction. In wastewater treatment systems, aeration is necessary for minimizing $\mathrm{C}$ and $\mathrm{N}$ overloads but favors concomitantly nitrate formation; thus, a reduction of $\mathrm{N}_{2} \mathrm{O}$ emissions is not easy to achieve. Ploughing soils and organic amendments with varying wide $\mathrm{CN}$ ratios intend to stimulate $\mathrm{O}_{2}$ diffusion and SOM degradation for reaching satisfying yields, which are easier realized by overloading agricultural land with mineral $\mathrm{N}$ fertilizers. An uncontrolled denitrification results instead of a more controlled one by organic amendments. Yet, high groundwater $\mathrm{NO}_{3}^{-}$contents and increasing $\mathrm{N}_{2} \mathrm{O}$ emissions force farmers to overthink their fertilization concepts whereby nitrification inhibitor stabilized fertilizers are seen as the solution (Zerulla et al. 2001). The concept behind this is to follow nature's $\mathrm{C}_{\mathrm{H} 2 \mathrm{O}} / \mathrm{NO}_{3}{ }^{-}$ratio managing strategy, which also includes nitrificationinhibiting compounds. The aim is to prevent $\mathrm{NO}_{3}{ }^{-}$formation especially during the plant-free period, to balance the $\mathrm{C}_{\mathrm{H} 2 \mathrm{O}} / \mathrm{NO}_{3}{ }^{-}$ratio towards $\mathrm{C}_{\mathrm{H} 2 \mathrm{O}}$ surplus. Despite all endeavors undertaken by ecologists, waste managers, farmers, and the industry in replacing oil based by renewable energy sources, the atmospheric $\mathrm{N}_{2} \mathrm{O}$ concentration continues to increase by annually $0.25 \%$ (Michel and Wozniak 1998; Eurostat yearbook, statistical guide to Europe, European Commission 2013). New, politically claimed models must be developed for being more precise in predicting $\mathrm{NO}_{3}{ }^{-}$and $\mathrm{N}_{2} \mathrm{O}$ impacts on ground waters, ecosystems, and climate (Crutzen et al. 2008; PICC MAT 2011; Lienhard et al. 2014). Climate change alters ecological strategies of soil bacteria and thus triggers shifts within taxa, $\mathrm{C}_{\mathrm{H} 2 \mathrm{O}} / \mathrm{NO}_{3}{ }^{-}$ratio and soil community composition (Evans and Wallenstein 2014).

\section{$9 \mathrm{C}_{\mathrm{H} 2 \mathrm{O}} / \mathrm{NO}_{3}{ }^{-}$ratio managing possibilities}

Nature has shaped a soil $\mathrm{C}_{\mathrm{H} 2 \mathrm{O}} / \mathrm{NO}_{3}{ }^{-}$ratio concept inter alia to control nitrification and denitrification. The concept includes plant diversity, animal activity, the distribution of organic matter (energy source) and electron acceptors, inorganic nutrients, and nitrification inhibiting compounds. The intention is to force denitrifying bacteria and archaea residing in waterfilled soil crumb zones, compost clots, wastewater flocks or earthworm guts to use the electron acceptors $\mathrm{NO}_{3}{ }^{-}, \mathrm{NO}_{2}{ }^{-}$, $\mathrm{NO}$, and $\mathrm{N}_{2} \mathrm{O}$ economically (Figs. 3 and 8; Table 2; Simarmata et al. 1993; Horn et al. 2006; Benckiser 2010). Have nitrate ions reached the groundwater, the chance to be reduced decreases. There is also little chance that escaped $\mathrm{N}_{2} \mathrm{O}$ molecules from the cell membrane into the surrounding atmosphere are further reduced to $\mathrm{N}_{2}$ (Lin et al. 2008; Vieten et al. 2008). Compost with a mean $\mathrm{CN}$ ratio of around 15 and a $\mathrm{C}_{\mathrm{H} 2 \mathrm{O}} / \mathrm{NO}_{3}{ }^{-}$ratio of around 1000 and spread on agricultural land shapes the nitrification-denitrification activities in soils and is thus a possibility to reduce $\mathrm{N}_{2} \mathrm{O}$ emissions (Barth et al. 2008; Beylich et al. 2010; PICCMAT 2011; Langevin et al. 2014). Though laboratory experiments with soil $\mathrm{C} \mathrm{NO}_{3}{ }^{-}$ratios between 84 and 130 exhibited that as soon as $\mathrm{NO}_{3}{ }^{-}$is widely exhausted $\mathrm{N}_{2} \mathrm{O}$ is reduced to $\mathrm{N}_{2}$ even in the presence of $\mathrm{C}_{2} \mathrm{H}_{2}$, a $\mathrm{N}_{2} \mathrm{O}$ emission reduction with organic amendments is not easy to achieve (Simarmata et al. 1993; Chen et al. 2013). A controlled nitrate availability is easier achieved with nitrification inhibitors as nature is exemplifying it with compounds like karanjin, humic acids, or neem (Hassett et al. 1987; Majumder et al. 2001; Abasi et al. 2011). Nitrification inhibitors not only downsize the nitrification but also control the follower process, denitrification (Fig. 2). Nitrification inhibitors as dicyandiamide or 3,4-dimethylpyrazole phosphate unveil a $\mathrm{N}_{2} \mathrm{O}$ reduction efficiency of 25.8 or $48.7 \%$ especially during the plant's free and early growth periods when only little of the forming or fertilized nitrate is taken up (Table 2; Weiske et al. 2001; Chang et al. 1998; Akiyama et al. 2010). In liquid culture, the $\mathrm{N}_{2} \mathrm{O}$ reducing efficiency by the nitrification inhibitors 3,4-dimethylpyrazole phosphate, $N$-allylthiourea, dimethylether, or nitrapyrin is around $95 \%$ and thus significantly higher than in soils (Fig. 7; Table 2), presumably because the soil clay-humus complex fixes parts of the added $\mathrm{NH}_{4}^{+}$.

An ideal inhibitor, environmentally applied, should penetrate the low concentrated target cell and only influence the envisaged enzyme. It should not too rapidly degrade, not suffer from a high degree of adsorption, not affect other processes and organisms, and not interfere with analytical procedures required during the experiment (Miller et al. 1993). In field experiments with the nitrification inhibitors dicyandiamide and 3,4-dimethylpyrazole phosphate, it was found that the AMO resembling MMO was not curtailed (Table 2; Holmes et al. 1995). That signalizes a highly specific enzyme blocking 
of both inhibitors. The existing analysis for dicyandiamide and the analysis for 3,4-dimethylpyrazole phosphate developed by us enabled to show that both $\mathrm{N}_{2} \mathrm{O}$ emissions reducing nitrification inhibitors disappeared, the 3,4-dimethylpyrazole phosphate less rapidly than dicyandiamide (Rajbanshi et al. 1992; Weiske et al. 2001; Benckiser et al. 2013). Thus, both NI seemingly fulfill the criteria for an ideal inhibitor. The still unexplained $\mathrm{CO}_{2}$ emission reduction, especially in the presence of 3,4-dimethylpyrazole phosphate (Table 2), relativizes the conclusion drawn before.

In a 10-day laboratory incubation experiment with 3,4dimethylpyrazole phosphate, stabilized ASN granules placed on a silty clay soil, adjusted to a water holding capacity of $24 \%$, showed that 3,4-dimethylpyrazole phosphate remained in this time frame to $80 \%$ within the 0 - to 5 -mm region around the fertilizer granule (Azam et al. 2001). Only 5-15\% moved 5-20 mm away from the granule and $<3 \%$ into the $25-40 \mathrm{~mm}$ region. In the same time frame, ammonium diffused $4 \mathrm{~cm}$ away from the fertilizer granule and nitrate showed a fairly uniform distribution. In conclusion, $4 \mathrm{~cm}$ away from the fieldapplied 3,4-dimethylpyrazole phosphate stabilized fertilizer granule ammonium oxidizing bacteria, archaea, and denitrifying bacteria and archaea can continue oxidizing $\mathrm{NH}_{4}{ }^{+}$to $\mathrm{NO}_{3}{ }^{-}$and reducing $\mathrm{NO}_{3}{ }^{-}$to $\mathrm{N}_{2} \mathrm{O}$ and $\mathrm{N}_{2}$, while the proximate granule neighborhood is protected. Dicyandiamide and 3,4-dimethylpyrazole phosphate, applied at recommended rates, evidently do not affect the essential soil processes in temperate climate regime conditions (Tindaon et al. 2012), but this might be different at soil temperature regimes above $30^{\circ} \mathrm{C}$ (Ali et al. 2008; 2012). Under hot climate soil conditions, dicyandiamide and also 3,4-dimethylpyrazole phosphate are less resistant to degradation, in an alkaline calcareous soil dicyandiamide even seems to increase the fertilizer $\mathrm{N}$ loss and a satisfying AMO inhibition is first achieved when the application rate of dicyandiamide and 3,4-dimethylpyrazole phosphate is at least 10 times higher than the recommended one for temperate climate regimes (16\%, dicyandiamide, or $1.6 \%$ 3,4-dimethylpyrazole phosphate to $\mathrm{NH}_{4}{ }^{+}-\mathrm{N}$; Mahmood et al. 2011). A 10 times higher 3,4-dimethylpyrazole phosphate application rate than the recommended one for temperate climate regimes given to a liquid medium growing nitrifying bacteria consortium exhibited that after a 75-day incubation even the target organisms not recovered (Benckiser et al. 2013). A 10 times higher 3,4-dimethylpyrazole phosphate soil applied rate than the recommended one for temperate climate regimes will affect the nitrifying microbial community less drastically because of absorption phenomena and low diffusion velocity (Azam et al. 2001; Tindaon et al. 2012). Dicyandiamide and 3,4-dimethylpyrazole phosphate-related soil (field) studies carried out by Di et al. (2007) and Kleineidam et al. (2011) indicate that both nitrification inhibitors may insufficiently block the archaeal AMO. But these first hints need to be proven and a continuing nitrification inhibitor stabilized fertilizer development may improve the inhibition efficiency in combination with an advancing ploughing technology (inorganic-organic mixing and $\mathrm{O}_{2}$-diffusion improvement), intercropping (improved $\mathrm{NO}_{3}{ }^{-}$uptake), $\mathrm{N}$ requirement adapted fertilization, or a crop, field properties adapted precision farming farmers (Bouma 2014; Langevin et al. 2014). This bouquet of possibilities helps to influence and control nitrate formation and $\mathrm{N}_{2} \mathrm{O}$ emissions in agricultural landscapes better in future. In a present cost/benefit analysis of farming practices of the European Commission (EC), the $\mathrm{EC}$ hesitates to recommend the use of nitrification inhibitor stabilized $\mathrm{N}$ fertilizers in spite of a 26 to $49 \% \mathrm{~N}_{2} \mathrm{O}$ emission reduction, because they are still relatively costly and their side effect behavior is insufficiently tested (PICCMAT 2011). Also, the crop yield improvement of cereals and maize in presence of nitrification inhibitors is not conclusively documented. In this context, a better comprehension of modern analysis such as the ${ }^{15} \mathrm{~N}^{14} \mathrm{~N}$ isotope ratio technique would be helpful in shaping $\mathrm{C}_{\mathrm{H} 2 \mathrm{O}} / \mathrm{NO}_{3}{ }^{-}$ratio-dependent $\mathrm{N}_{2} \mathrm{O}$ emissions more satisfyingly in our industrializing world by combining in a plant $\mathrm{N}$ demand adapted the application of animal manure, plant residues, compost, and nitrification inhibitor stabilized $\mathrm{N}$ fertilizers (Sturm and Lojen 2011; Decock and Six 2013). Plants growing on animal manure-enriched fields accumulate due to the animal transaminase activity in such fertilizers ${ }^{15} \mathrm{~N}$ in their tissue to around $+10 \pm 4 \%$, while plants grown in fields receiving different mixtures of inorganic plant residue fertilizers may enrich in their tissues ${ }^{15} \mathrm{~N}$ by around $4 \%$ and plants grown on fields receiving legume residues or exclusively mineral fertilizers show no accumulation of ${ }^{15} \mathrm{~N}$. Precision farming and waste management escorted by ecologists and advising agencies, and continually improving analysis-based techniques may in the future enable waste managers and farmers to sustain satisfying yields at reduced $\mathrm{N}$ inputs or satisfying organic load degradation at well-balanced $\mathrm{C}_{\mathrm{H} 2 \mathrm{O}} / \mathrm{NO}_{3}{ }^{-}$ratios and reduced $\mathrm{N}_{2} \mathrm{O}$ emissions.

\section{Conclusion}

Converted primary forest and permafrost soils into monoculture agroecosystems, industrially organized waste recycling systems, and industries are sources for increasing atmospheric $\mathrm{N}_{2} \mathrm{O}$ emissions. Landscape managers have two options for reducing the $\mathrm{N}_{2} \mathrm{O}$ increase:

a. To suppress denitrification by enriching the system with $\mathrm{O}_{2}$, whereby nitrification and organic matter degradation are favored, and

b. Balancing the water soluble carbon $\left(\mathrm{C}_{\mathrm{H} 2 \mathrm{O}}\right) / \mathrm{NO}_{3}{ }^{-}$soil ratio appropriately with animal manure, compost, and/or nitrification inhibitor stabilized $\mathrm{N}$ fertilizers. 
The aim of all measures is to organize energy conservation hierarchically and in a way that anaerobic $\mathrm{NO}_{3}{ }^{-}$respiration majorly ends as $\mathrm{N}_{2} \cdot \mathrm{C}_{\mathrm{H} 2 \mathrm{O}} / \mathrm{NO}_{3}{ }^{-}$ratio balancing towards a surplus of electron donors at anaerobic denitrifying conditions force denitrifying bacteria, archaea, and fungi to use the electron acceptors $\mathrm{NO}_{3}{ }^{-}, \mathrm{NO}_{2}{ }^{-}, \mathrm{NO}$, and $\mathrm{N}_{2} \mathrm{O}$ economically by reducing them mostly to $\mathrm{N}_{2}$. Such balanced $\mathrm{C}_{\mathrm{H} 2 \mathrm{O}} / \mathrm{NO}_{3}{ }^{-}$ratios are easier to achieve with nitrification inhibitor stabilized $\mathrm{N}$ fertilizers than with the application of organic materials. Nitrification inhibitors control nitrification specifically and consequently the following process, denitrification. In shaping $\mathrm{C}_{\mathrm{H} 2 \mathrm{O}} / \mathrm{NO}_{3}{ }^{-}$ratios, analysis such as the ${ }^{15} \mathrm{~N}^{14} \mathrm{~N}$ isotope ratio technique may be helpful. They allow better insights in Ntransformations. From a climate point of view, complete prevention of $\mathrm{NO}_{3}^{-}$leaching and $\mathrm{N}_{2} \mathrm{O}$ emissions is not a reality and even not desirable.

\section{References}

Abasi MK, Hina M, Tahir MM (2011) Effect of Azadirachta indica (Neem), sodium thiosulphate and calcium chloride on changes in nitrogen transformation and inhibition of nitrification in soil incubated under laboratory conditions. Chemosphere 82:1629-1635. doi:10.1016/j.chemosphere.2010.11.044

Akiyama H, Yan X, Yagi K (2010) Evaluation of effectiveness of enhanced-efficiency fertilizers as mitigation options for $\mathrm{N}_{2} \mathrm{O}$ and $\mathrm{NO}$ emissions from agricultural soils: metaanalysis. Glob Chang Biol 16:1837-1846. doi:10.1111/j.1365-2486.2009.02031.x

Ali R, Iqbal J, Tahir GR, Mahmood T et al (2008) Effect of 3,5dimethylpyrazole and nitrapyrin on nitrification under high soil temperature. Pak J Bot 40:1053-1062

Ali R, Latif S, Kanwal H et al (2012) Evaluation of some nitrification inhibitors at different temperatures under laboratory conditions. Soil Environ 31:134-145

Aparna K, Pasha MA, Rao DLN et al (2014) Organic amendments as ecosystem engineers: microbial, biochemical and genomic evidence of soil health improvement in a tropical arid zone field site. Ecol Eng 71:268-277. doi:10.1016/j.ecoleng.2014.07.016

Arcand MM, Knight JD, Farrell RE (2013) Estimating belowground nitrogen inputs of pea and canola and their contribution to soil inorganic $\mathrm{N}$ pools using ${ }^{15} \mathrm{~N}$ labeling. Plant Soil: 320 doi:10.1007/ s11104-013-1626-z

Azam F, Benckiser G, Mueller C et al (2001) Release, movement and recovery of 3,4-dimethylpyrazole phosphate (DMPP), ammonium and nitrate from stabilized fertilizer granules in a silty clay soil under laboratory conditions. Biol Fertil Soils 34:118-125. doi:10.1007/ s003740100384

Babikova Z, Gilbert L, Bruce TJA et al (2013) Underground signals carried through common mycelial networks warn neighbouring plants of aphid attack. Ecol Lett 16:835-843. doi:10.1111/ele.12115

Bardgett RD, Wardle DA (2010) Above-belowground linkages: biotic interactions, ecosystem processes and global change. Oxford University Press, Oxford, p 320. doi:10.1111/j.1442-9993.2012. 02405.x

Barth J, Amlinger F, Favoino E et al (2008) Organic recovery \& biological treatment orbit e.V./European Compost Network ECN http:// susproc.jrc.ec.europa.eu/activities/waste/ec.europa.eu/clima/ policies/eccp/index_en.htm
Benckiser G, Santiago S, Neue HU et al (1984) Effect of fertilization on exudation, dehydrogenase activity, iron reducing populations in the rhizosphere of rice (Oryza sativa L.) in relation to iron toxicity. Plant Soil 79:305-316

Benckiser G, Gaus G, Syring KM et al (1987) Denitrification losses from an inceptisol field treated with mineral fertilizer or sewage sludge. $Z$ Pflanzenern Bodenk 150:241-248. doi:10.1080/00380768.2012. 711220

Benckiser G, Eilts R, Linn A, Lorch $\mathrm{HJ}$ et al (1996) $\mathrm{N}_{2} \mathrm{O}$ emissions from different cropping systems and from aerated, nitrifying and denitrifying tanks of a municipal waste water treatment plant. Biol Fertil Soils 23:257-265. doi:10.1007/BF00335953

Benckiser G, Simarmata T (1994) Environmental impact of fertilizing soils by using sewage and animal wastes. Fert Res 37:1-22

Benckiser G (1997) Organic inputs and soil metabolism. In: Benckiser G (ed) Fauna in soil ecosystems. Marcel Dekker, New York, pp 7-62, http://books.google.de/books/content?id= H5bZySCJbnQC\&printsec $=$ frontcover\&img $=1 \&$ zoom $=1 \&$ edge $=$ curl\&imgtk=AFLRE73vPjhAEO6ncXHgse-hcNxm2814 W H S V B s GQKAT XU q e yu RW f 852 Hb 8 e J kutkj3x9nKK 5JOsbqdER6TzHxwqDoDNI1QwxLYP3C0n1r9PqyXLyVTeHKfZBiqVyzCT1QpboyeA2

Benckiser G (2007a) Growth, denitrification and nitrate ammonification of the rhizobial strain TNAU 14 in presence and absence of $\mathrm{C}_{2} \mathrm{H}_{4}$ and $\mathrm{C}_{2} \mathrm{H}_{2}$. Ann Microbiol 57:509-514

Benckiser G (2007b) Principles behind order and sustainability in natural successions and agriculture. In: Benckiser G, Schnell S (eds) Biodiversity in agricultural production systems. Taylor and Francis, Boca Raton, pp 349-383, books.google.com

Benckiser G (2010) Ants and sustainable agriculture. A review. Agric Sustain Dev 30:191-199. doi:10.1051/agro/2009026

Benckiser G, Bamforth SS (2011) Role of pathogens, signal recalcitrance, and organisms shifting for ecosystem recuperation. Rev Agric Sustain Dev 31:205-215. doi:10.1051/agro/2010024

Benckiser G, Christ E, Herbert T, Weiske A, Blome J, Hardt M (2013) The nitrification inhibitor 3,4-dimethylpyrazole-phosphate (DMPP) - quantification and effects on soil metabolism. Plant Soil. doi:10.1007/s11104-013-1664-6

Benckiser G, Ladha JK, Wiesler F (2015) Climate change and nitrogen turnover in soils and aquatic environments. In: Marxsen J (ed) Climate change, current research and future trends. Caister Academic, Norfolk

Beylich A, Oberholzer HR, Schrader S et al (2010) Evaluation of soil compaction effects on soil biota and soil biological processes in soils. Soil Till Res 109:133-143. doi:10.1016/j.still.2010.05.010

Blagodatskaya E, Kuzyakov Y (2013) Active microorganisms in soil: critical review of estimation criteria. Soil Biol Biochem 67:192211. doi:10.1016/j.soilbio.2013.08.024

Bollmann A, Conrad R (1997) Acetylene blockage technique leads to underestimation of denitrification rates in oxic soils due to scavenging of intermediate nitric oxide. Soil Biol Biochem 29:1067-1077. doi:10.1016/S0038-0717(97)00007-2

Bouma J (2014) Soil science contributions towards sustainable development goals and their implementations: linking soil functions with ecosystem services. J Plant Nutr Soil Sci 177:111-120. doi:10.1002/ jpln.201300646

Braker G, Dörsch P, Bakken LR (2012) Genetic characterization of denitrifier communities with contrasting intrinsic functional traits. FEMS Microbiol Ecol 79:542-554. doi:10.1111/j.1574-6941.2011. 01237.x

Bremner JM, Blackmer AM (1981) Terrestrial nitrification as a source of atmospheric nitrous oxide. In: Delwiche CC (ed) Denitrification, nitrification and atmospheric $\mathrm{N}_{2}$. Wiley, Chichester, pp 151-170

Burford JR, Bremner JM (1975) Relationship between the denitrification capacities of soils and total water-soluble readily decomposable soil 
organic matter. Soil Biol Biochem 7:389-394. doi:10.1016/00380717(75)90055-3

Burns RG, DeForest JL, Marxsen J et al (2013) Soil enzymes in a changing environment: current knowledge and future directions. Soil Biol Biochem 58:216-234. doi:10.1016/j.soilbio.2012.11.009

Burth I, Benckiser G, Ottow JCG (1982) $\mathrm{N}_{2} \mathrm{O}$-Freisetzung aus Nitrit; Denitrification durch ubiquitäre Pilze unter anaeroben Bedingungen. Naturwissenschaften 69:598-599

Cabello P, Roldan MD, Moreno-Vivian C (2004) Nitrate reduction and the nitrogen cycle in archaea. Microbiology 150:3527-3546. doi:10. 1099/mic.0.27303-0

Carvalhais LC, Dennis PG, Fedoseyenko D et al (2011) Root exudation of sugars, amino acids, and organic acids by maize as affected by nitrogen, phosphorus, potassium, and iron deficiency. J Plant Nutr Soil Sci 174:3-11. doi:10.1002/jpln.201000085

Chander K, Brooks PC (1991) Microbial biomass dynamics during decomposition of glucose ans maize in metal-contaminated and noncontaminated soils. Soil Biol Biochem 23:909-915

Chang C, Janzen HH, Cho CM et al (1998) Nitrous oxide emission through plants. Soil Sci Soc Am J 62:35-38. doi:10.2136/ sssaj1998.03615995006200010005x

Chapman S, Langley JA, Hart SC, Koch GW (2006) Plants actively control nitrogen cycling: uncorking the microbial bottleneck. New Phyt 169:27-34. doi:10.1111/j.1469-8137.2005.01571.x

Chen H, Li X, Hu F et al (2013) Soil nitrous oxide emissions following crop residue addition: a meta-analysis. Glob Chang Biol 19:295629564. doi:10.1111/gcb.12274

Christie P, Kilpatrick DJ (1992) Vesicular-Arbuscular mychorrhiza infections in cut grassland following long-term slurry application. Soil Biol Biochem 24:325-330. doi:10.1016/0038-0717(92)90192-Z

Crutzen PJ, Mosier AR, Smith KA et al (2008) $\mathrm{N}_{2} \mathrm{O}$ release from agrobiofuel production negates global warming reduction by replacing fossil fuels. Atmos Chem Phys 8:385-389. doi:10.5194/acp-8-3892008

Decock C, Six J (2013) How reliable is the intramolecular distribution of ${ }^{15} \mathrm{~N}$ in $\mathrm{N}_{2} \mathrm{O}$ to source partition $\mathrm{N}_{2} \mathrm{O}$ emitted from soil? Soil Biol Biochem 65:114-127. doi:10.1016/j.soilbio.2013.05.012

de Klein CAM, Cameron KC, Di HJ et al (2011) Repeated annual use of the nitrification inhibitor dicyandiamide (DCD) does not alter its effectiveness in reducing $\mathrm{N}_{2} \mathrm{O}$ emissions from cow urine. Animal Feed Sci Technol 166-167:480-491. doi:10.1016/j.anifeedsci.2011. 04.076

De Long EF (2012) Microbial evolution in the wild. Science 336:422424. doi:10.1126/science. 1221822

Depkat-Jakob PS, Hilgarth M, Horn MA et al (2010) Effect of earthworm feeding guilds on ingested dissimilatory nitrate reducers and denitrifiers in the alimentary canal of the earthworm. App Environ Microbiol 76:6205-6214. doi:10.1128/AEM.01373-10

Di HJ, Cameron KC, Sherlock RR (2007) Comparison of the effectiveness of a nitrification inhibitor, dicyandiamide (DCD), in reducing nitrous oxide emissions in four different soils under different climatic and management conditions. Soil Use Manag 23:1-9. doi:10. $1111 / j .1475-2743.2006 .00057 . x$

Engelhardt T, Sahlberg M, Cypionka H et al (2013) Biogeography of rhizobium radiobacter and distribution of associated temperate phages in deep subseafloor sediments. ISME J 7:199-209. doi:10. 1038/ismej.2012

Eurostat yearbook, statistical guide to Europe, European Commission (2013) epp.eurostat.ec.europa.eu/statistics/indexEurostat_ yearbook/de

Evans SE, Wallenstein MD (2014) Climate change alters ecological strategies of soil bacteria. Ecol Lett 17:155-164. doi:10.1111/ele.12206

Fey A, Benckiser G, Ottow JCG (1999) Emissions of nitrous oxide from a constructed wetland using a groundfilter and macrophytes in wastewater purification of a dairy farm. Biol Fertil Soils 29:354-359. doi: $10.1007 / \mathrm{s} 003740050565$
Filip Z, Kanazawa S, Berthelin J (2000) Distribution of microorganisms, biomass ATP, and enzyme activities in organic and mineral particles of a long-term wastewater irrigated soil. J Plant Nutr Soil Sci 163: 143-150. doi:10.1002/(SICI)1522-2624(200004)163:2<143::AIDJPLN143>3.0.CO;2-T

Flasconaro ML, Sanchez-Diaz M, Antolin MC (2013) Nitrogen metabolism is related to improved water-use efficiency of nodulated alfalfa grown with sewage sludge under drought. J Plant Nutr Soil Sci 176: 110-117. doi:10.1002/jpln.201100393

Flemming HG, Wingender J (2010) The biofilm matrix. Nat Rev Microbiol 8:623-633. doi:10.1038/nrmicro2415

Fungo $\mathrm{B}$, Guerena D, Thiongo $\mathrm{M}$ et al (2014) $\mathrm{N}_{2} \mathrm{O}$ and $\mathrm{CH}_{4}$ emission from soil amended with steam-activated biochar. J Plant Nutr Soil Sci 177:34-38. doi:10.1002/jpln.201300495

Fytili D, Zabiotou A (2008) Utilization of sewage sludge in EU application of old and new methods. Rev Renew Sus Energy Rev 12:116 140. doi:10.1016/j.rser.2006.05.014

Gross M (2012) We need to talk about nitrogen. Curr Biol 22:R1-R4

Hallinger S, Wallnöfer PR, Goldbach H et al (1990) Several aspects of bacterial dicyandiamide degradation. Naturwiss 77:332-334

Hangs RD, Schoenau JJ, Lafond GP (2013) The effect of nitrogen fertilization and no-till duration on soil nitrogen supply power and postspring thaw greenhouse-gas emissions. J Plant Nutr Soil Sci 176: 227-237. doi:10.1002/jpln.201200242

Hassett DJ, Bisesi MS, Hartenstein R (1987) Bactericidal action of humic acids. Soil Biol Biochem 19:111-113

Henry S, Texier S, Hallet S et al (2008) Disentangling the rhizosphere effect on nitrate reducers and denitrifiers: insight into the role of root exudates. Environ Microbiol 10:3082-3092. doi:10.1111/j.14622920.2008.01599.x

Holmes AJ, Costello A, Lidstrom ME et al (1995) Evidence that particulate methane monooxygenase and ammonia monooxygenase may be evolutionarily related. FEMS Microbiol Lett 132:203-208. doi: 10.1111/j.1574-6968.1995.tb07834.x

Horn MA, Mertel R, Gehre M et al (2006) In vivo emission of dinitrogen by earthworm via denitrifying bacteria in the gut. Appl Environ Microbiol 72:1013-1018. doi:10.1128/AEM.72.2.1019-1026.2006

Huang Y, Zoub J, Zhenga X et al (2004) Soil nitrous oxide emissions as influenced by amendment of plant residues with different $\mathrm{C}: \mathrm{N}$ ratios. Biol Biochem 36:973-981. doi:10.1016/j.soilbio.2004.02.009

Hungate RE (1966) The rumen and its microbes. Academic, NY

Kehr J (2006) Phloem sap proteins: their identities and potential roles in the interaction between plants and phloem-feeding insects. J Exp Bot 57:767-774. doi:10.1093/jxb/erj087

Kilian A, Gutser R, Claasen N (1998) $\mathrm{N}_{2} \mathrm{O}$ emissions following longterm fertilization at different levels. Agribiol Res 51:27-36

Kleineidam K, Košmrlj K, Kublik S et al (2011) Influence of the nitrification inhibitor 3,4-dimethylpyrazole phosphate (DMPP) on ammonia-oxidizing bacteria and archaea in rhizosphere and bulk soil. Chemosphere 84:182-186. doi:10.1016/j.chemosphere.2011. 02.086

Klemedtsson L, von Arnold K, Weslien P et al (2005) Soil CN ratio as a scalar parameter to predict nitrous oxide emissions. Glob Chang Biol 11:1142-1147. doi:10.1111/j.1365-2486.2005.00973.x

Klüber HD, Conrad R (1998) Effects of nitrate, nitrite and $\mathrm{N}_{2} \mathrm{O}$ on methanogenesis and other redox processes in anoxic rice field soil. FEMS Microbiol Ecol 25:301-318. doi:10.1111/j.1574-6941.1998. tb00482.x

Koper TE, El-Sheik AF, Norton JM et al (2004) Urease-encoding genes in ammonia-oxidizing bacteria. Appl Environ Microbiol 70:23422348. doi:10.1128/AEM.70.4.2342-2348.2004

Lal R (2005) World crop residues production and implications of its use as a biofuel. Environ Int 31:575-584. doi:10.1128/AEM.70.4.23422348.2004 
Lambers DH, Weidensaul TC (1991) Element uptake by mycorrhizal soybean from sewage sludge treated soil. Soil Sci Soc Am J 55: 393-398

Lambers H, Brundrett MC, Raven JA et al (2011) Plant mineral nutrition in ancient landscapes: high plant species diversity on infertile soils is linked to functional diversity for nutritional strategies. Plant Soil 348:7-27. doi:10.1007/s11104011-0977-6

Langevin B, Genermont S, Basset-Mens C et al (2014) Simulation of field $\mathrm{NH}_{3}$ and $\mathrm{N}_{2} \mathrm{O}$ emissions from slurry spreading. Agron Sustain Dev. doi:10.1007/s13593-014-0248-Z

Law Y, Ye L, Pan Y et al (2012) Nitrous oxide emissions from wastewater treatment processes. Philos Trans R Soc Lond B Biol Sci 367:12651277. doi:10.1098/rstb.2011.0317

Leverenz HL, Haunschild K, Hopes G, Tchobanoglous G, Darby Jeannie L (2010) Anoxic treatment wetlands for denitrification. Ecol Eng 36: 1544-1551. doi:10.1016/j.ecoleng.2010.03.014

Li H, Xi L, Chen Y et al (2008) Effect of nitrification inhibitor DMPP on nitrogen leaching, nitrifying organisms and enzyme activities in a rice-oil seed rape cropping system. J Environ Sci 20:149-155. doi: 10.1016/S1001-0742(08)60023-6

Lienhard P, Terrat S, Prévost-Bouré NC et al (2014) Pyrosequencing evidences the impact of cropping on soil bacterial and fungal diversity in Laos tropical grassland. Agric Sustain Dev 34:525-533. doi: 10.1007/s13593-013-0162-9

Lin YF, Jing SR, Lee DY, Chang YF, Shih KC (2008) Nitrate removal from groundwater using constructed wetlands under various hydraulic loading rates. Biores Tech 99:7504-7513. doi:10.1016/j.biortech. 2008.02.017

Madariaga GM, Angle JS (1992) Sludge borne salt effects on survival of Bradyrhizobium japonicum. J Environ Qual 21:276-280. doi:10. 2134/jeq1992.00472425002100020020x

Mahmood T, Ali R, Latif Z, Ishaque W (2011) Dicyandiamide increases the fertilizer $\mathrm{N}$ loss from an alkaline calcareous soil treated with $15 \mathrm{~N}$-labelled urea under warm climate and under different crops. Biol Fertil Soils 147:619-631. doi:10.1007/s00374-011-0559-Z

Majumder D, Datta A, Kumar S, Pathak H, Jain MC (2001) Mitigation of $\mathrm{N}_{2} \mathrm{O}$ emission from an alluvial soil by application of karanjin (3 methoxyfurano $2^{\prime}, 3^{\prime}, 7,8$ flavone) as nitrification inhibitor in different soil types. Biol Fertil Soils 33:438-442. doi:10.1007/ s003740100342

Malhotra J, Aparna K, Dua A, Sangwan N, Trimurtulu N, Rao DLN, Lal R (2015) Microbial and genetic ecology of tropical Vertisols under intensive chemical farming. Environ Monit Assess 187:4081-4086. doi:10.1007/s10661-014-4081-2

Mc Carty GW (1999) Modes of action of nitrification inhibitors. Biol Fertil Soils 29:1-9. doi:10.1007/s003740050518

Michel HJ, Wozniak H (1998) Düngung, Nitrifikation und Denitrifikation aus der Sicht klimaverändernder Gasemissionen - ein Überblick. Agribiol Res 51:3-11

Miller LG, Coutlakis MD, Oremland RS, Ward BB (1993) Selective inhibition of ammonium oxidation and nitrification-linked $\mathrm{N}_{2} \mathrm{O}$ formation by methylfluoride and dimethylether. Appl Environ Microbiol 59:2457-2464

Morgan JE, Morgan AJ (1992) Heavy metal concentrations in the tissue, ingesta and faeces of ecophysiologically different earthworm species. Soil Biol Biochem 24:1691-1697. doi:10.1016/0038-0717(92) 90171-S

Nacry P, Bouguyon E, Gojon A (2013) Nitrogen acquisition by roots: physiological and developmental mechanisms ensuring plant adaptation to a fluctuating resource. Plant Soil 370:1-29

Ottow JCG (2011) Mikrobiologie von Böden. Springer, Heidelberg

Pauli B, O’Malley P (2008) Compost production and use in horticulture. Bulletin 4746, Western Australian Agriculture Authority. SSN 1833 7236
Philips S, Wyffels S, Sprengers R, Verstraete W (2002) gen-limited autotrophic nitrification/denitrification by ammonia oxidisers enables upward motion towards more favourable conditions. Appl Microbiol Biotech 59:557-566

PICCMAT (2011) Politic Incentives for Climate Change Mitigation Agricultural Techniques for an agricultural policy towards the year $2020 \mathrm{http}: /$ www.climatechangeintelligencebaastel.be/piccmat/ index.php

Poth M, Focht DD (1985) $15 \mathrm{~N}$ kinetic analysis of $\mathrm{N}_{2} \mathrm{O}$ production by Nitrosomonas europaea: an examination of nitrifier denitrification. Appl Environ Microbiol 49:1134-1141

Poth M (1986) Dinitrogen production from nitrite by a Nitrosomonas isolate. Appl Environ Microbiol 51:957-959

Powell SJ, Prosser JI (1986) Inhibition of ammonium oxidation by nitrapyrin in soil and liquid culture. Appl Environ Microbiol 52: 782-787

Purcell DA, Raven AM, Thompson RH (1971) High nitrogen grass cubes as a source of nitrite poisoning in cattle. Res Vet Sci 12:598-600

Rajbanshi SS, Benckiser G, Ottow JCG (1992) Effects of concentration, incubation temperature and repeated applications on degradation kinetics of dicyandiamide (DCD) in soils. Biol Fertil Soils 13:6164. doi:10.1007/BF00337336

Ravishankara AR, Daniel JS, Portmann RW (2009) Nitrous oxide $\left(\mathrm{N}_{2} \mathrm{O}\right)$ : the dominant ozone-depleting substance emitted in the 21st century. Science 326:23-125. doi:10.1007/BF00337336

Rockström J, Steffen W, Noone K et al (2009) A safe operating space for humanity. Nature 461:472-475

Roldan A, Alexander J (1993) Veriscular-Arbuscular mychorrhiza (VAM) fungal populations in a xeric torriorthent receiving urban refuse. Soil Biol Biochem 24:451-456. doi:10.1016/00380717(93)90070-R

Säwström C, Anesio MA, Graneli W, Laybourn-Parry J (2007) Seasonal viral loop dynamics in two large ultraoligotrophic Antarctic freshwater lakes. Microb Ecol 53:1-11. doi:10.1007/s00248-006-9146-5

Schwarz J, Kapp M, Benckiser G, Ottow JCG (1994) Evaluation of denitrification losses by the acetylene inhibition technique in a permanent ryegrass field (Lolium perenne L.) fertilized with animal slurry or ammonium nitrate. Biol Fertil Soils 18:327-333. doi:10. 1007/BF00570636

Scherer HW (1993) Dynamics and availability of the non-exchangeable NH4-N_ - review. Eur J Agronom 2:149-160. doi:10.1016/S11610301(14)80124-X

Simarmata T, Benckiser G, Ottow JCG (1993) Effect of an increasing carbon:nitrate- $\mathrm{N}$ ratio on the reliability of acetylene in blocking the N2O-reductase activity of denitrifying bacteria in soil. Biol Fertil Soils 15:107-112. doi:10.1007/BF00336427

Sime-Ngando T (2014) Environmental bacteriophages: viruses of microbes in aquatic ecosystems. Front Microbiol. doi:10.3389/fmicb. 2014.00355

Steffen W, Persson A, Deutsch L, Zalasiewicz J, Williams M, Richardson K, Crumley C, Crutzen P, Folke C, Gordon L, Molina M, Veerabhadran R, Rockstrom J, Scheffer M, Schellnhuber HJ, Svedin U (2011) The anthropocene: from global change to planetary stewardship. Ambio 40:739-761. doi:10.1007/s13280-011-0185-x

Strohm TO, Griffin B, Zumft WG, Schink B (2007) Growth yields in bacterial denitrification and nitrate ammonification. Appl Environ Microbiol 73:1420-1424. doi:10.1128/AEM.02508-06

Strous M, van Gerven E, Zheng P, Kuenen JG, Jetten MSM (1997) Ammonium removal from concentrated waste streams with the anaerobic ammonium oxidation (Anammox) process in different reactor configurations. Water Res 131:1955-1962

Sturm M, Lojen S (2011) Nitrogen isotopic signature of vegetables from the Slovenian market and its suitability as an indicator of organic production. Iso Env Helth Stud 47:214-220

Sturm H, Buchner A, Zerulla W (1994) Gezielter Düngen. Verlags Union Agrar, Frankfurt 
Sutton MA, Oenema O, Erisman JW, Leip A, van Grinsven H, Winiwarter W (2011) Too much of a good thing. Nature 472:159161

Syring KM, Benckiser G (1990) Modeling denitrification losses from arable land. Mitteilungen Deutsche Bodenkundliche Gesellschaft 60:403-406

Tadeno R, Takeda H (2010) Nitrogen uptake and nitrogen use efficiency above and below ground along a topographic gradient of soil nitrogen availability. Oecologia 163:793-804

Tiedje JM (1988) Ecology of denitrification and dissimilatory nitrate reduction to ammonium. In: Zehnder AJB (ed) Biology and anaerobic organisms. Wiley, New York, pp 179-244

Tindaon F, Benckiser G, Ottow JCG (2012) The nitrification inhibitor 3, 4-dimethylpyrazole-phosphate (DMPP) - quantification and effects on soil metabolism. Biol Fertil Soils. doi:10.1007/s00374-0110655-0

Taroncher-Oldenburg G, Griner EM, Francis CA, Ward BB (2003) Oligonucleotide microarray for the study of functional gene diversity in the nitrogen cycle in the environment. Appl Environ Microbiol 69:1159-1171. doi:10.1128/AEM.69.2.1159-1171.2003

Toma Y, Hatano R (2007) Effect of crop residue C: $\mathrm{N}$ ratio on $\mathrm{N}_{2} \mathrm{O}$ emissions from Gray Lowland soil in Mikasa, Hokkaido. Japan Soil Sci Plant Nut 53:198-205. doi:10.1111/j.1747-0765.2007.00125.x

Trost B, Prchnow A, Drastig K, Meyer-Aurich A, Ellmer F, Baumecker $\mathrm{M}$ (2013) Irrigation, soil organic carbon and $\mathrm{N}_{2} \mathrm{O}$ emissions. Rev Agron Sustain Dev 33:733-749. doi:10.1007/s13593-013-0134-0

Vega S, Calisay M, Hue NY (1992) Manganese toxicity in cowpea as affected by soil $\mathrm{pH}$ and sewage sludge amendments. J Plant Nutr 15: 219-231. doi:10.1080/01904169209364314

Vieten B, Conen F, Seth B, Alewell C (2008) The fate of $\mathrm{N}_{2} \mathrm{O}$ consumed in soils. Biogeosciences 5:129-132. doi:10.5194/bg-5-129-2008

Wagner M, Rath G, Amann R, Koops HP, Schleifer KH (1995) In situ identification of ammonia-oxidizing bacteria. Syst Appl J Microbiol 18:251-264. doi:10.1016/S0723-2020(11)80396-6
Wallensten MD, Myrold DD, Firestone M, Voytek M (2006) Environmental controls on denitrifying communities and denitrification rates: insights from molecular methods. Ecol Appl 15:21432152. doi:10.1890/1051-0761(2006)016[2143:ECODCA]2.0.CO;2

Weiske A, Benckiser G, Ottow JCG (1995) Quantifizierung von gelöstem Lachgas $\left(\mathrm{N}_{2} \mathrm{O}\right)$ in Abwasser-, Boden-, und Kompost. VDLUFA Schriftenreihe 40:623-626

Weiske A, Benckiser G, Ottow JCG (2001) Effect of the new nitrification inhibitor 3,4-dimethylpyrazole phosphate (DMPP) in comparison to dicyandiamide (DCD) on nitrous oxide $\left(\mathrm{N}_{2} \mathrm{O}\right)$ emission and methane $\left(\mathrm{CH}_{4}\right)$ oxidation during 3 years repeated application in field experiments. Nutr Cycl Agroecosys 60:57-64

Weiss B, Larink O (1991) Influence of sewage sludge and heavy metals on nematodes. Biol Fertil Soils 12:5-9. doi:10.1007/BF00369381

Wiesler F (1998) Comparative assessment of efficacy of various nitrogen fertilizers. J Crop Prod 1:81-114. doi:10.1300/J144v01n02 04

Xu L, Chen H, Xu JJ, Yang JB, Li XC, Liu MQ, Jiao JG, Hu F (2014) Nitrogen transformation and plant growth in response to different urea-application methods and the addition of DMPP. J Plant Nutr Soil Sci 177:271-277. doi:10.1002/jpln.201100390

Yu Z, Deng H, Wang D, Ye M, Tan Y, Li Y, Chen Z, Xu S (2013) Nitrous oxide emissions in the Shanghai river network: implications for the effects of urban sewage and IPCC methodology. Global Chang Biol 19:2999-3010. doi:10.1111/gcb.12290

Zerulla W, Barth T, Dressel J, Erhardt K, Horchler von Locquenghien K, Pasda G, Rädle M, Wissemeier AH (2001) 3,4-Dimethylpyrazole phosphate (DMPP) - a new nitrification inhibitor for agriculture and horticulture. Introduct Biol Fertil Soils 34:79-84. doi:10.1007/ s003740100380

Zhang JB, Müller C, Zhu TB, Yi C, Cai ZC (2011) Heterotrophic nitrification is the predominant $\mathrm{NO}_{3}{ }^{-}$production mechanism in coniferous but not broad-leaf acid forest soil in subtropical China. Biol Fertil Soils 47:533-542. doi:10.1007/s00374-011-0567-z

Zumft WG (1997) Cell biology and molecular basis of denitrification. Microbiol Mol Biol Rev 61:533-536 